\title{
Pathogenetic role of eNOS uncoupling in cardiopulmonary disorders
}

Citation for published version (APA):

Gielis, J. F., Lin, J. Y., Wingler, K., Van Schil, P. E. Y., Schmidt, H. H., \& Moens, A. L. (2011).

Pathogenetic role of eNOS uncoupling in cardiopulmonary disorders. Free Radical Biology and Medicine, 50(7), 765-776. https://doi.org/10.1016/j.freeradbiomed.2010.12.018

Document status and date:

Published: 01/04/2011

DOI:

10.1016/j.freeradbiomed.2010.12.018

Document Version:

Publisher's PDF, also known as Version of record

Document license:

Taverne

Please check the document version of this publication:

- A submitted manuscript is the version of the article upon submission and before peer-review. There can be important differences between the submitted version and the official published version of record.

People interested in the research are advised to contact the author for the final version of the publication, or visit the DOI to the publisher's website.

- The final author version and the galley proof are versions of the publication after peer review.

- The final published version features the final layout of the paper including the volume, issue and page numbers.

Link to publication

\footnotetext{
General rights rights.

- You may freely distribute the URL identifying the publication in the public portal. please follow below link for the End User Agreement:

www.umlib.nl/taverne-license

Take down policy

If you believe that this document breaches copyright please contact us at:

repository@maastrichtuniversity.nl

providing details and we will investigate your claim.
}

Copyright and moral rights for the publications made accessible in the public portal are retained by the authors and/or other copyright owners and it is a condition of accessing publications that users recognise and abide by the legal requirements associated with these

- Users may download and print one copy of any publication from the public portal for the purpose of private study or research.

- You may not further distribute the material or use it for any profit-making activity or commercial gain

If the publication is distributed under the terms of Article $25 \mathrm{fa}$ of the Dutch Copyright Act, indicated by the "Taverne" license above, 
Review Article

\title{
Pathogenetic role of eNOS uncoupling in cardiopulmonary disorders
}

\author{
Jan F. Gielis ${ }^{\text {a }}$, Judy Y. Lin ${ }^{\text {b }}$, Kirstin Wingler ${ }^{c}$, Paul E.Y. Van Schil ${ }^{\text {a }}$, Harald H. Schmidt ${ }^{c}$, An L. Moens ${ }^{\text {b,* }}$ \\ a Department of Vascular and Thoracic Surgery, University of Antwerp, Antwerp, Belgium \\ b Department of Cardiology, Cardiovascular Research Institute Maastricht, Maastricht University Medical Center, 6202 AZ Maastricht, The Netherlands \\ c Department of Pharmacology, Cardiovascular Research Institute Maastricht, Maastricht University Medical Center, 6202 AZ Maastricht, The Netherlands
}

\section{A R T I C L E I N F O}

\section{Article history:}

Received 5 September 2010

Revised 14 November 2010

Accepted 10 December 2010

Available online 21 December 2010

\section{Keywords:}

eNOS uncoupling

Superoxide

Tetrahydrobiopterin

eNOS modulators

Cardioprotection

Free radicals

\begin{abstract}
A B S T R A C T
The homodimeric flavohemeprotein endothelial nitric oxide synthase (eNOS) oxidizes L-arginine to L-citrulline and nitric oxide (NO), which acutely vasodilates blood vessels and inhibits platelet aggregation. Chronically, eNOS has a major role in the regulation of blood pressure and prevention of atherosclerosis by decreasing leukocyte adhesion and smooth muscle proliferation. However, a disturbed vascular redox balance results in eNOS damage and uncoupling of oxygen activation from L-arginine conversion. Uncoupled eNOS monomerizes and generates reactive oxygen species (ROS) rather than NO. Indeed, eNOS uncoupling has been suggested as one of the main pathomechanisms in a broad range of cardiovascular and pulmonary disorders such as atherosclerosis, ventricular remodeling, and pulmonary hypertension. Therefore, modulating uncoupled eNOS, in particular eNOS-dependent ROS generation, is an attractive therapeutic approach to preventing and/or treating cardiopulmonary disorders, including protective effects during cardiothoracic surgery. This review provides a comprehensive overview of the pathogenetic role of uncoupled eNOS in both cardiovascular and pulmonary disorders. In addition, the related therapeutic possibilities such as supplementation with the eNOS substrate L-arginine, volatile NO, and direct NO donors as well as eNOS modulators such as the eNOS cofactor tetrahydrobiopterin and folic acid are discussed in detail.
\end{abstract}

(c) 2010 Published by Elsevier Inc.

\section{Contents}

Introduction . . . . . . . 766

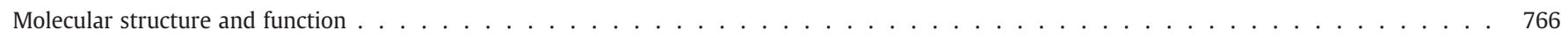

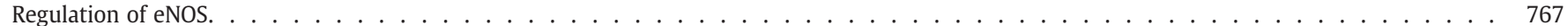

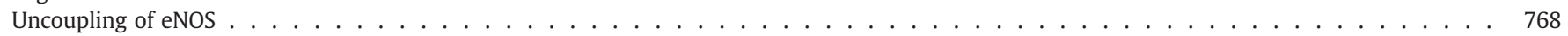

Role of eNOS uncoupling in the cardiovascular system . . . . . . . . . . . . . . . . . . . . . . . . . . . . . . . 769

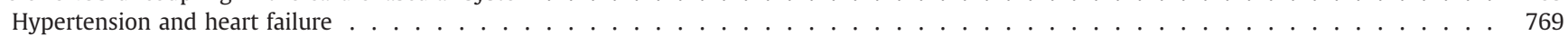

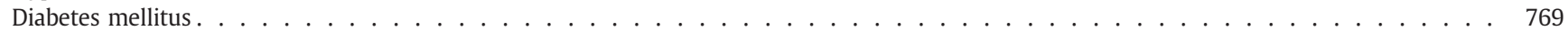

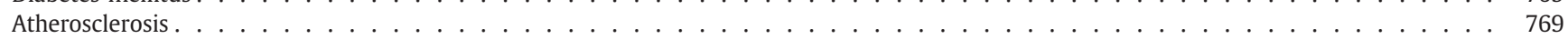

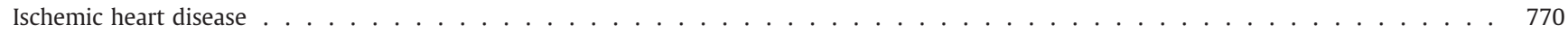

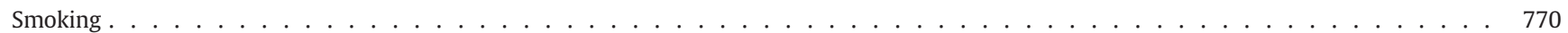

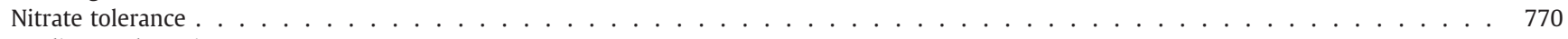

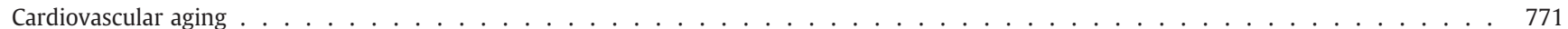

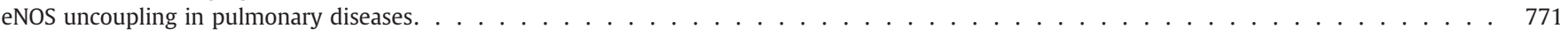

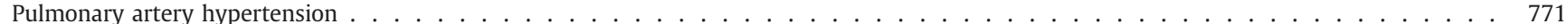

Acute lung injury and acute respiratory distress syndrome . . . . . . . . . . . . . . . . . . . . 771

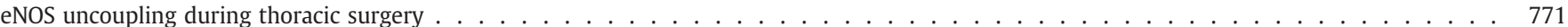

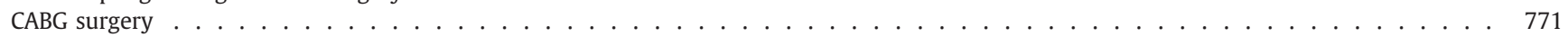

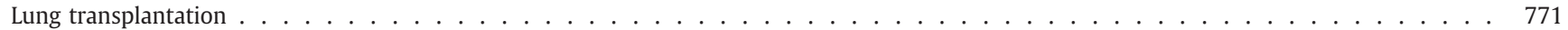

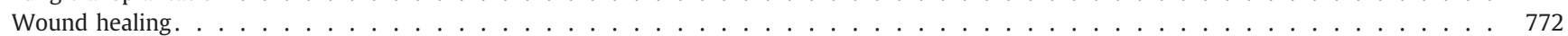

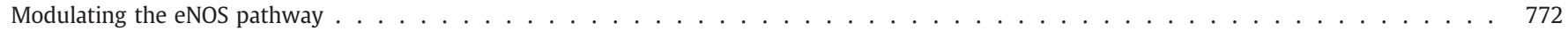

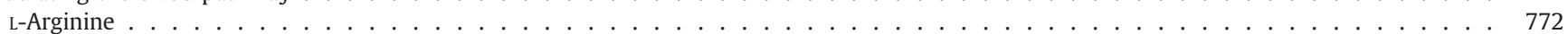

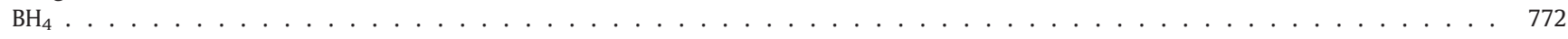

\footnotetext{
* Corresponding author. Fax: +31433872870.

E-mail address: an.moens@mumc.nl (A.L. Moens).
} 


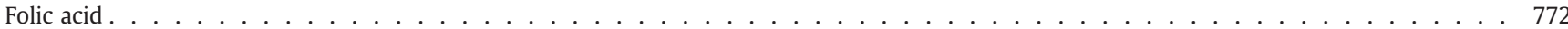

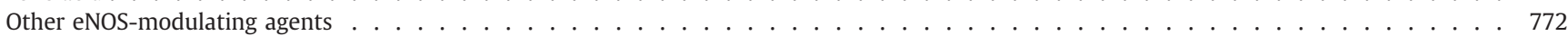

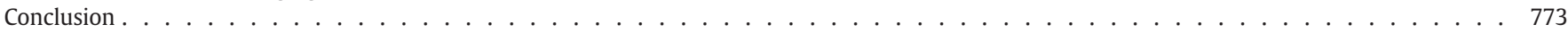

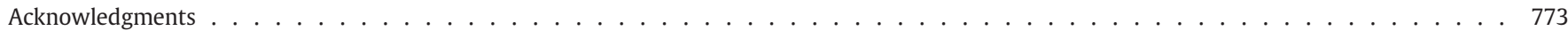

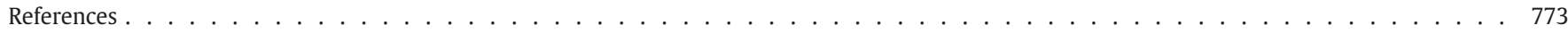

\section{Introduction}

It has been 30 years since Furchgott and Zawadski demonstrated that the endothelium produces a mysterious "endothelium-derived relaxing factor," which is responsible for vascular smooth muscle relaxation [1]. This was followed by the remarkable observation that this factor was the freely diffusible gas nitric oxide (NO) [2]. Today, NO is regarded as one of the body's most versatile molecules. It is a neurotransmitter, second messenger, inflammatory marker, and therapeutic agent that is generated by nitric oxide synthases (NOS). NOS catalyze the conversion of the amino acid L-arginine[3] and molecular oxygen to L-citrulline and NO, aided by cofactors. Three NOS isoforms have been identified, i.e., neuronal NOS (NOS-I), inducible NOS (NOS-II), and endothelial NOS (NOS-III; eNOS).

Endothelial NOS, as its name suggests, is mainly found in the endothelial lining of the blood vessels but also in the cardiomyocytes [4], airway epithelium [5], tubular cells of the kidney [6], and other organ systems. The cardiovascular system relies on eNOS for optimal function, most notably with NO as the principle mediator of flowmediated dilation. In addition to blood pressure regulation, eNOSderived NO is also responsible for inhibition of platelet aggregation, leukocyte adhesion, and smooth muscle cell proliferation (see Fig. 1 for the structure of eNOS) [7]. Consequently, functional impairment of this enzyme may result in endothelial dysfunction, leading to both pulmonary and systemic hypertension. Most actions of NO are mediated via the production of cGMP by guanylate cyclase, resulting in a decreased intracellular calcium $\left(\mathrm{Ca}^{2+}\right)$ concentration. Lower intracellular $\mathrm{Ca}^{2+}$ results in relaxation of the vascular smooth muscle layer and ultimately in vasodilatation and a decrease in blood pressure.

In this review, we discuss the molecular basis of eNOS uncoupling, the regulation of eNOS activity, its physiological functions in the cardiopulmonary system, and its role in the physiopathology of various cardiovascular and pulmonary diseases.

\section{Molecular structure and function}

eNOS is a homodimer that binds a number of different cofactors, which are required to convert L-arginine and $\mathrm{O}_{2}$ to L-citrulline and NO. Each eNOS monomer has a bidomain structure. The N-terminus comprises the oxygenase domain and contains tetrahydrobiopterin $\left(\mathrm{BH}_{4}\right)$, heme iron, and L-arginine binding sites. L-Arginine and $\mathrm{BH}_{4}$ promote enzyme dimerization and both act as a stabilizer of the active dimeric form $[8,9]$. The heme group is also essential for dimerization [10]. Further stabilization is generated by a zinc thiolate $\left(\mathrm{ZnS}_{4}\right)$ cluster formed by a zinc ion between two cysteine residues from each monomer. This cluster is responsible for the integrity of the $\mathrm{BH}_{4}$ binding site [11]. The C-terminus is the reductase domain with binding sites for two flavins, flavin adenine dinucleotide (FAD) and flavin mononucleotide (FMN), and NADPH [12]. Electrons are produced by oxidation of NADPH to $\mathrm{NADP}^{+}$at the flavin domain of each monomer [12]. These electrons are then transferred, one at a

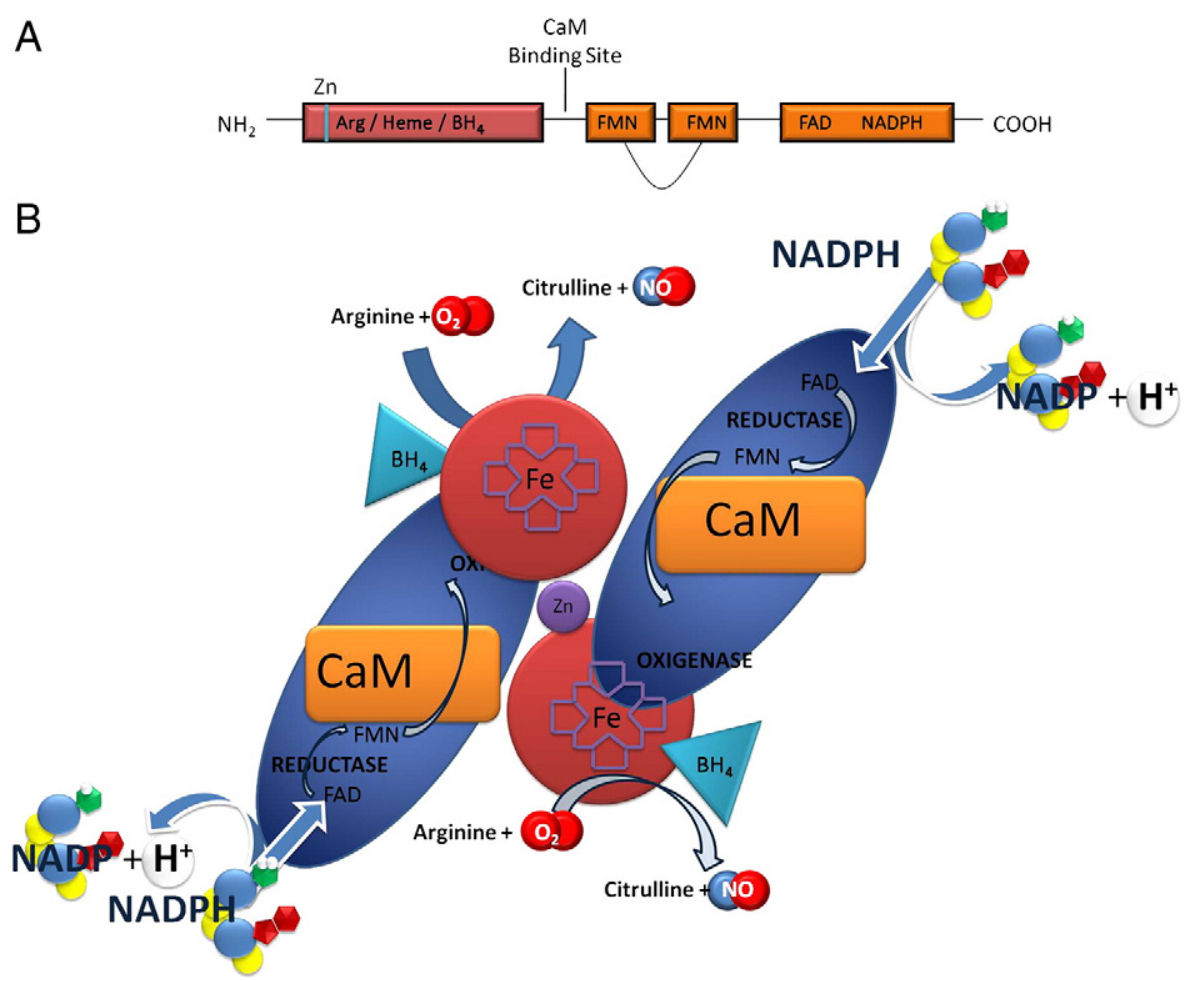

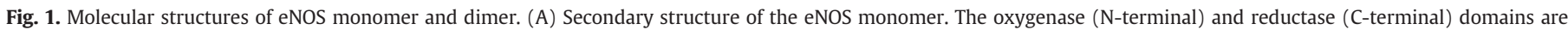

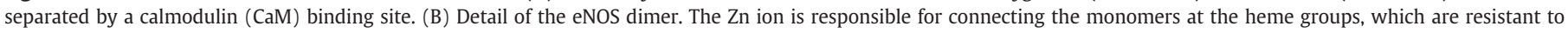

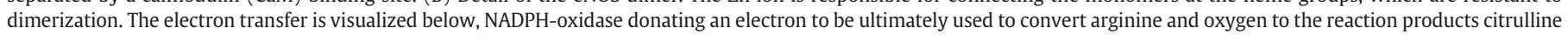
and nitric oxide. Tetrahydrobiopterin $\left(\mathrm{BH}_{4}\right)$ further stabilizes the dimer. $\mathrm{Zn}$, zinc; Arg, arginine binding site; FMN, flavin mononucleotide; FAD, flavine adenine dinucleotide. 
time, to the prosthetic heme iron of the oxygenase domain, where reduction of molecular oxygen $\left(\mathrm{O}_{2}\right)$ to $\mathrm{O}_{2}^{-}$takes place. Bound L-arginine is then converted to NO and the by-product L-citrulline. This electron transfer onto heme is mediated by FAD [13]. The oxygenase is linked to the reductase domain by an inhibitory calmodulin binding domain. To be active, eNOS has to be deinhibited by the binding of two calcium-activated calmodulins, which secure the electron transfer from the reductase to the oxygenase domain (Fig. 2) [14].

\section{Regulation of eNOS}

eNOS is predominantly targeted to the sarcolemmal caveolae, which are invaginations of the plasma membrane. Here the enzyme is bound by posttranslational myristoylation and palmitoylation to caveolin-1, a resident coat protein that inhibits eNOS activity. Caveolin-1 interacts with the calmodulin (CaM) binding sites and inhibits the electron transfer from NADPH at the reductase to the heme molecule in the oxygenase domain. At a cellular level, eNOS is therefore activated by a calcium-mediated disruption of the eNOScaveolin heteromeric complex. Caveolin-free eNOS is then translocated from the caveolae to the cytoplasm. Its enzymatic function there is greatly upregulated, including also $\mathrm{Ca}^{2+}$-independent steps. As a result, the electron flow from the reductase to the oxygenase domain is initiated, and NO is produced. In addition, in the caveolae the substrate L-arginine is recycled from L-citrulline, ensuring a sufficient pool for eNOS [15-17]. In addition, eNOS activity is influenced by posttranslational modifications, such as calcium influx, and phosphorylation at various amino acid residues [18]. Calcium-activated CaM is essential for rapid enzyme activation, although in vivo eNOS may become calcium independent through a reduction in $\mathrm{CaM}$ dissociation from activated eNOS [19]. Phosphorylation is of key importance in regulating the overall function, activation, and, potentially, coupling of eNOS. This includes phosphorylation of calmodulin, caveolin, and amino acid residues on eNOS itself. The production of both NO and superoxide by eNOS can be modulated by protein kinase $\mathrm{C} \alpha$ (PKC $\alpha$ )-mediated phosphorylation of calmodulin and caveolin. Phosphorylation of eNOS at Ser1177 is pivotal in the direct regulation of superoxide versus NO generation, altering both the calcium sensitivity of the enzyme and the rate of reaction product formation [20]. In detail, direct phosphorylation of Ser1177 by adenine monophosphate kinase (AMPK) enhances eNOS activity by promoting its association with heat shock protein 90 [21]. This is also true for the uncoupled eNOS, for which Akt-mediated phosphorylation of Ser1177 markedly enhances maximal superoxide generation at low levels of calcium, making NO generation largely calcium independent [19]. However, phosphorylation at Thr495 at the CaM binding domain prevents the increase in catalytic activity of eNOS by hindering the association of CaM with eNOS [22]. In addition, phosphorylation at Ser633 in the FMN binding domain has been associated with increased enzyme activity after initial activation by $\mathrm{Ca}^{2+}$ influx and Ser1177 phosphorylation [18]. eNOS can also be phosphorylated at Ser114 and Ser615, but the functions of these phosphorylation sites remain controversial [23].

$\mathrm{BH}_{4}$ is obligatory for optimal eNOS activity. First, it ensures normal function at the heme catalytic site. In the absence of $\mathrm{BH}_{4}$, reduction of the ferric ion of the eNOS heme group translates to the formation of an $\mathrm{Fe}(\mathrm{II})$ dioxygen complex, resulting in superoxide formation. In the presence of $\mathrm{BH}_{4}$, iron-oxy species are formed, which participate in Larginine hydroxylation and thus in NO generation. Second, it increases eNOS affinity for L-arginine [24]. Third, it is hypothesized to play a role

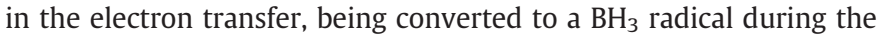
first catalytic reaction [25]. Fourth, $\mathrm{BH}_{4}$ interacts with amino acid residues from both monomers to stabilize dimerization [26]. In addition, $\mathrm{BH}_{4}$ can act as a modest scavenger of reactive oxygen (ROS) and nitrogen species.

$\mathrm{BH}_{4}$ can be oxidized by ROS, leading to a reduction in vascular $\mathrm{BH}_{4}$ and an increase in vascular $\mathrm{BH}_{2}$ availability [27]. A lack of this crucial cofactor results in decreased eNOS function and a further increase in ROS production combined with a decrease in NO production $[28,29]$. In addition the oxidation product, $\mathrm{BH}_{2}$, is a competitive $\mathrm{BH}_{4}$ antagonist [30].

$\mathrm{BH}_{4}$ was initially described as the oxygen acceptor and cofactor for aromatic amino acid hydroxylases, involved in neurotransmitter biosynthesis. In eNOS, however, heme is the oxygen receptor and

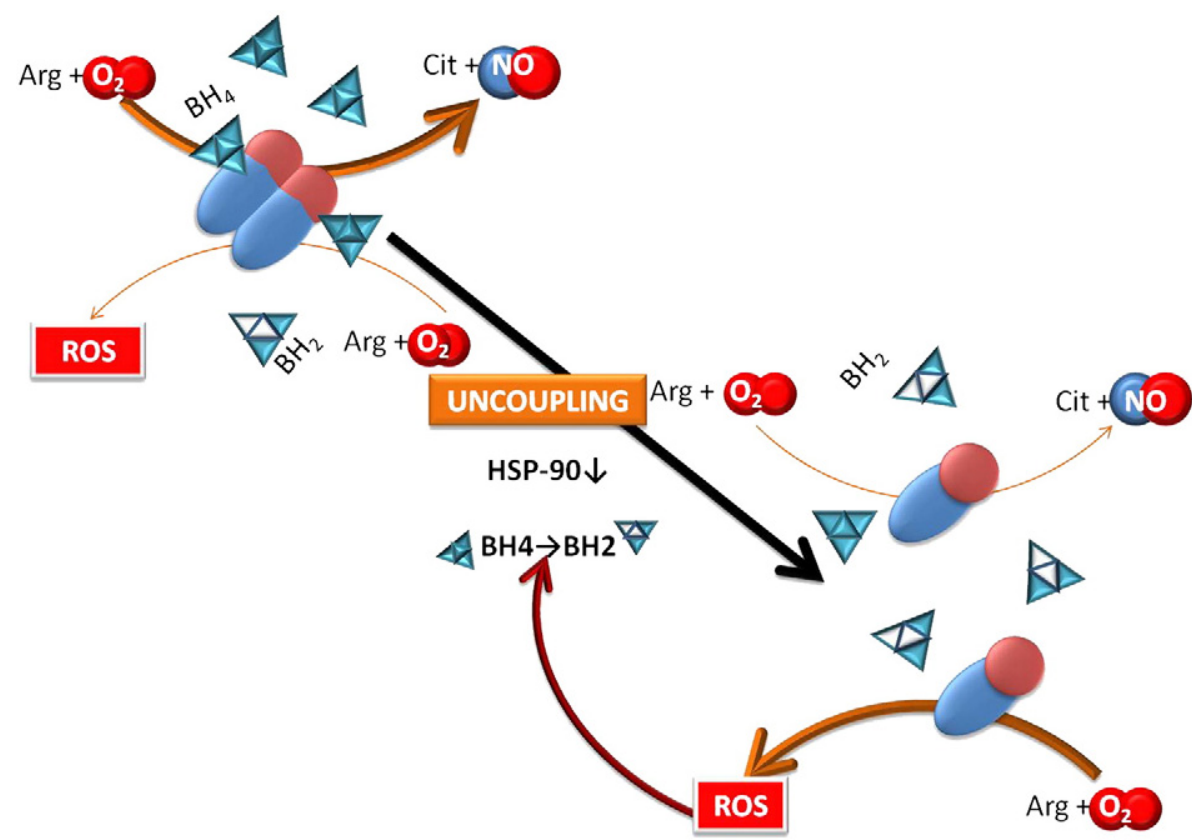

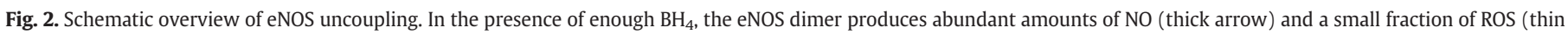

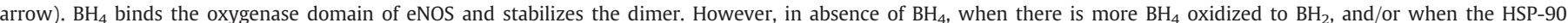

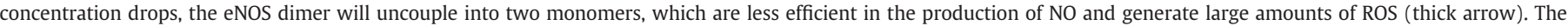

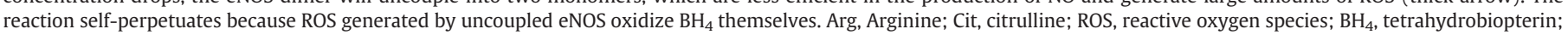
$\mathrm{BH}_{2}$, dihydrobiopterin; HSP, heat shock protein. 
$\mathrm{BH}_{4}$ has different functions. $\mathrm{BH}_{4}$ can be formed through two different pathways, i.e., a de novo and a salvage pathway (Fig. 3). The de novo synthesis of $\mathrm{BH}_{4}$ starts with guanidine triphosphate, which is converted by guanidine triphosphate cyclohydrolase-1 (GTPCH-1) and sepiapterin reductase to $\mathrm{BH}_{4}$. GTPCH-1 is the rate-limiting enzyme in the biosynthesis of $\mathrm{BH}_{4}$. It is inhibited by the specific GTPCH feedback regulatory protein and is under positive feedback by phenylalanine [31]. This regulation takes place by altering the transcription levels, and thus, the production of $\mathrm{BH}_{4}$ is largely dependent on GTPCH-1 expression. Transcription is increased by inflammatory factors such as tumor necrosis factor- $\alpha$, interleukin-1, interferon- $\gamma$, and lipopolysaccharides [32]. GTPCH-1 is localized in the caveolar microdomains of the cardiomyocyte together with caveolin1 and eNOS [33], where it provides a continual source of $\mathrm{BH}_{4}$. GTPCH-1 expression is also determined by the GTPCH-1 haplotype [34]. Certain autosomal-dominant inherited mutations in the GTPCH-1 enzyme lead to congenital $\mathrm{BH}_{4}$ deficiency and neurological symptoms known as dopa-responsive dystonia [35]. In mammals, the main salvage pathway progresses through dihydrofolate reductase (DHFR) and dihydropteridin reductase (DHPR). DHFR mainly activates folic acid to 5-methyltetrahydrofolate and also regenerates $\mathrm{BH}_{4}$ from its oxidized form $\mathrm{BH}_{2}$. DHPR uses the quinonoid form of $\mathrm{BH}_{2}$ as substrate.

\section{Uncoupling of eNOS}

Uncoupling of eNOS can be visualized by SDS-polyacrylamide gel electrophoresis as a loss of the eNOS dimer and an increase in the monomer-to-dimer ratio [36]. The uncoupled state can thus also be interpreted as an altered quaternary structure of the enzyme.

Vasquez-Vivar et al. [30] demonstrated the effects of $\mathrm{BH}_{4}$ on the balance between $\mathrm{NO}$ and superoxide formation. In absence of $\mathrm{BH}_{4}$, eNOS becomes uncoupled and cannot reach its normal NOgenerating abilities. Once eNOS is uncoupled because of decreased bioavailability of $\mathrm{BH}_{4}$, the uncoupling propagates because uncoupled eNOS generates superoxide, which will oxidize the remaining $\mathrm{BH}_{4}$
[27]. Superoxide may react with NO, forming peroxynitrite [37]. The increased activity of enzymes such as NADPH oxidases ignites a cascade of radical formation by producing superoxide as a kindling radical. Bursts of peroxynitrite oxidize $\mathrm{BH}_{4}$ to $\mathrm{BH}_{3}$, further increasing eNOS uncoupling, starting a bonfire of radical production by eNOS. Peroxynitrite can also lead to irreversible nitration of tyrosine residues on other proteins [38], causing impaired phosphorylation and enzymatic dysfunction [39].

Importantly, elevated eNOS expression, without a parallel increase in $\mathrm{BH}_{4}$, results in eNOS uncoupling because of an imbalance between the cofactor and the enzyme [40]. Crabtree et al. [41] investigated the stoichiometry of intracellular $\mathrm{BH}_{4} / \mathrm{eNOS}$ interactions and demonstrated a striking linear relationship between eNOS activity and cellular $\mathrm{BH}_{4}$ levels, with eNOS uncoupling occurring when the eNOS: $\mathrm{BH}_{4}$ molar ratio exceeded 1. Increasing intracellular $\mathrm{BH}_{2}$ concentration in the presence of a constant eNOS: $\mathrm{BH}_{4}$ ratio was sufficient to induce eNOS-dependent superoxide production, indicating that eNOS/ $\mathrm{BH}_{4}$ reaction stoichiometry has a tandem role with the intracellular $\mathrm{BH}_{4}$ : $\mathrm{BH} 2$ ratio (rather than absolute plasma concentrations of $\mathrm{BH}_{4}$ ) in determining eNOS uncoupling, even when exogenous oxidative stress is absent. In another recent study, Heiss et al. [42] demonstrated that a decrease in $\mathrm{BH}_{4}$ levels activates NF-E2-related factor, which leads to a reduction in eNOS protein levels in human endothelial cells. Thus, the stoichiometric balance between $\mathrm{BH}_{4}$ and eNOS is maintained, eNOS is kept in a coupled state, and ROS production is reduced. Crabtree et al. [41] showed that murine endothelial cells contain large amounts of DHFR and that reduction of DHFR activity by methotrexate, or genetic knockdown of DHFR by RNA interference, resulted in oxidation of $\mathrm{BH}_{4}$ to $\mathrm{BH}_{2}$ with subsequent eNOS uncoupling. DHFR can regenerate $\mathrm{BH}_{4}$ from $\mathrm{BH}_{2}$ and preserve eNOS coupling by helping to maintain a better $\mathrm{BH}_{4}: \mathrm{BH}_{2}$ ratio, especially when both are scarce.

The essential role of L-arginine in keeping eNOS coupled is debatable. It is unlikely that plasma L-arginine levels would fall below the critical concentration for eNOS activity in vivo, as the plasma level of L-arginine is 30 times higher than the eNOS $K_{\mathrm{M}}$

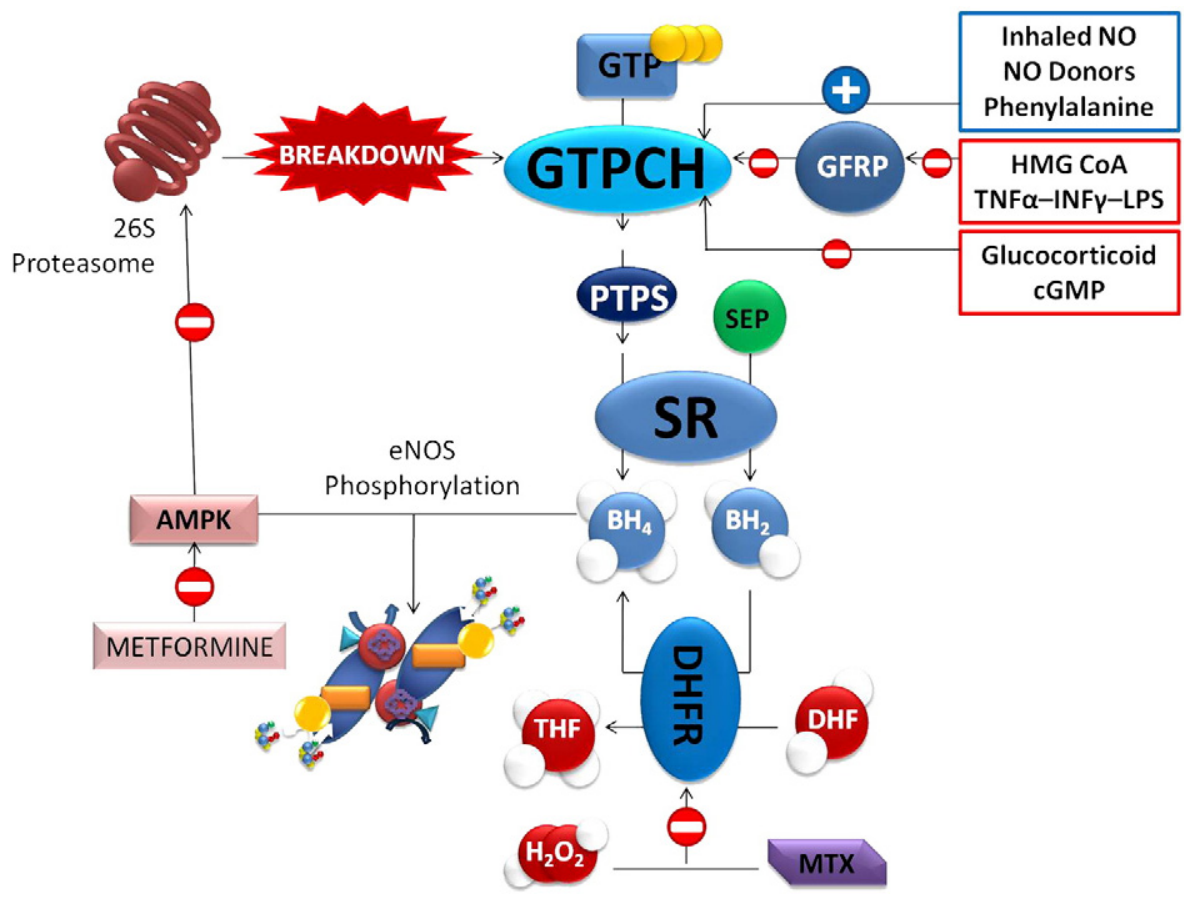

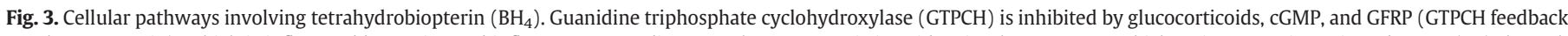

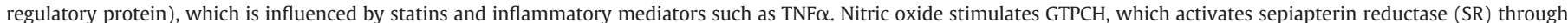

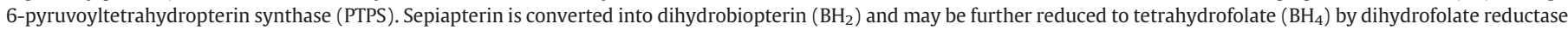

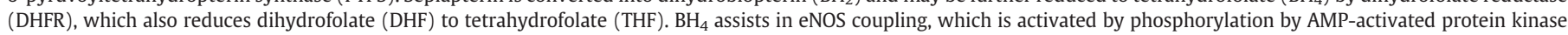
(AMPK). AMPK is inhibited by the antidiabetic agent metformin, and AMPK itself inhibits the 26S proteasome, thereby inhibiting breakdown of GTPCH. 
( $3 \mu \mathrm{mol} \cdot \mathrm{L}^{-1}$ vs $100 \mu \mathrm{mol} \cdot \mathrm{L}^{-1}$ ) [41]. In addition, $\mathrm{L}$-arginine itself is recycled by the cell [43]. An increased intracellular breakdown by arginases, however, can lead to a very local, subcellular decrease in intracellular L-arginine. As such, arginases, expressed in endothelial cells, can compete with eNOS for their common substrate [44] and can therefore also have downregulating effects on eNOS [45]. The eNOS inhibitor asymmetric dimethylarginine (ADMA) directly inhibits eNOS, and it also inhibits cellular L-arginine uptake by endothelial cells. Therefore, a decreased L-arginine:ADMA ratio can result in reduced NO formation by eNOS. Indeed, Antoniades et al. [46] demonstrated a strong inverse association between serum ADMA and levels of eNOS dimer, in both human arteries and human veins. Furthermore, increased ADMA plasma concentrations are associated with oxidative stress within the vessels and the development of endothelial dysfunction [47]. Thus rather than changes in L-arginine, changes in ADMA seem to trigger eNOS uncoupling. However, Druhan et al. [48] demonstrated that, although ADMA can uncouple eNOS and elevate ROS generation in the absence of $\mathrm{BH}_{4}$, this is not the fact when adequate levels of L-arginine are present. Also, in this study ADMA and L-arginine elevated ROS produced by uncoupled eNOS in equal fashions. This may indicate that ADMA is not responsible for eNOS uncoupling under physiological conditions.

The $\mathrm{ZnS}_{4}$ cluster in the eNOS oxygenase domain, formed by a zinc ion and two cysteine residues from each monomer, is positioned equidistant from each heme group and is responsible for the maintenance of the integrity of the $\mathrm{BH}_{4}$ binding site [11]. Mutation in this cluster prevents the binding of zinc, $\mathrm{BH}_{4}$, or L-arginine and eliminates enzyme activity [49], suggesting that stabilization of the dimer interface by the zinc thiolate center is one of the keys for catalytic activity. Exposing the isolated eNOS enzyme to peroxynitrite, a by-product of the interaction between excessive $\mathrm{NO}$ and $\mathrm{O}_{2}^{--}$, leads to the oxidation of the zinc thiolate cluster, which uncouples eNOS. Recently, Chen et al. [50] demonstrated that the dimer stabilization induced by $\mathrm{BH}_{4}$ does not require zinc occupancy in this thiolate cluster. Although peroxynitrite treatment induced loss of $\mathrm{Zn}$ binding and compromised eNOS activity, incubation with a zinc chelator did not alter eNOS activity.

\section{Role of eNOS uncoupling in the cardiovascular system}

\section{Hypertension and heart failure}

In mice, gene expression of eNOS influences vascular tone and hence is a major determinant of blood pressure regulation [51]. eNOS uncoupling in hypertension was first shown by Mollnau et al. [52] in an in vivo rat angiotensin II infusion model. Where deletion of the eNOS gene causes systemic hypertension [51], overexpression results in a reduction of blood pressure [53]. Landmesser et al. [27] demonstrated the pathogenetic role of eNOS uncoupling in DOCA salt hypertension. Later, Takimoto et al. [54] confirmed the key role of eNOS uncoupling in pressure-overload-induced ventricular remodeling using a model of transverse aortic constriction. They demonstrated that oral administration of $\mathrm{BH}_{4}$ to wild-type mice prevented cardiac hypertrophy and dilation, improved heart function, and inhibited eNOS uncoupling with a subsequent increase in NO synthesis and a decrease in ROS generation. In addition, this group showed that pressure overload in eNOS ${ }^{-1-}$ mice resulted in less cardiac hypertrophy, dilation, and a decrease in myocardial fibrosis because no eNOS was available to become uncoupled, and consequently, there was no detrimental NOS-dependent superoxide generation. Further, Moens et al. [55] demonstrated that oral administration of $\mathrm{BH}_{4}$ can restore uncoupled eNOS and reverse preexisting ventricular hypertrophy, fibrosis, and myocardial dysfunction. Treatment with a general antioxidant such as Tempol had no effect on eNOS and could not produce the same positive results on preexisting ventricular remodeling as $\mathrm{BH}_{4}$.

\section{Diabetes mellitus}

Insulin resistance induces eNOS uncoupling through increased superoxide production [56] in streptozotocin-induced diabetic LDL receptor-deficient mice. In the vessels of rats with streptozotocininduced diabetes both upregulation and uncoupling of eNOS are observed in a PKC-dependent process [57]. This is observed despite an increase in eNOS expression, suggesting that eNOS becomes uncoupled rather than downregulated. Diabetes mellitus (DM) type 2 is associated with increased nitrotyrosine formation mediated by peroxynitrite and subsequent endothelial dysfunction [58]. In mice treated with streptozotocin, which selectively destroys the $\beta$ cells of the pancreas, inducing DM, eNOS becomes uncoupled but also expressionally upregulated [59]. This results in a decrease in $\mathrm{BH}_{4}$ levels and compensatory GTPCH-1 overexpression in the endothelium of the diabetic aorta $[59,60]$. However, the influence of this GTPCH-1 overexpression is limited in light of uncoupled eNOS, and a subsequent decrease in $\mathrm{BH}_{4}$ is observed [60]. There is also evidence that GTPCH-1 is downregulated in diabetes and not compensatorily upregulated [61]. The dysfunction of endothelial progenitor cells in patients with DM 2 and the consequent lack of vascular repair have also been linked to eNOS uncoupling induced by $\mathrm{BH}_{4}$ deficiency [62]. Recently Wang et al. [63] described that a decrease in AMPK results in abnormal activity of the $26 \mathrm{~S}$ proteasome, leading to an accelerated destruction of GTPCH in a streptozotocin model of DM 2 in mice. In patients with DM 2, metformin, which activates AMPK, was shown to reduce mortality and improve vascular function. Inhibiting the breakdown of GTPCH- 1 by the $26 \mathrm{~S}$ proteasome via AMPK upregulation is therefore an additional pathway for maintaining normal eNOS activity.

\section{Atherosclerosis}

Oelze et al. [64] first demonstrated that eNOS uncoupling is at least partially involved in the increased ROS formation in the vessels of hyperlipidemic rabbits. Antoniades et al. [65] investigated the role of $\mathrm{BH}_{4}$ in atherosclerosis using saphenous veins and internal mammary arteries from patients with coronary artery disease (CAD) undergoing coronary bypass surgery. They found that plasma biopterin levels are inversely correlated with vascular biopterins, which are mostly present in the endothelium. Vascular $\mathrm{BH}_{4}$ levels were inversely correlated with vascular ROS generation and positively correlated with eNOS coupling and NO-mediated endothelial function. Plasma $\mathrm{BH}_{4}$ levels were also positively correlated with impaired endothelial function [65] and with C-reactive protein (CRP) levels, a prototypic marker of inflammation. The direct effects of CRP on cardiovascular risk are debated and CRP may better be regarded a marker of cardiovascular disease, rather than a mediator. The pathogenetic role of eNOS uncoupling is described in Fig. 4.

Proinflammatory stimuli are sufficient to increase the amount of circulating plasma biopterins, but fail to increase biopterin levels in the endothelium itself, leading to endothelial dysfunction by eNOS uncoupling. As described above, the specific GTPCH-1 haplotype of the patient determines the levels of $\mathrm{BH}_{4}$ in plasma and vascular endothelium [34]. This GTPCH haplotype [66] is defined by three single-nucleotide polymorphisms, rs8007267G $\rightarrow A$ in the putative promoter region, rs3783641 $\mathrm{A} \rightarrow \mathrm{T}$ in intron 1 , and $\mathrm{rs} 10483639 \mathrm{C} \rightarrow \mathrm{G}$ in the $3^{\prime}$ untranslated region of the GTPCH-1 gene, and is associated with increased vascular superoxide generation by uncoupled eNOS and decreased endothelial function, independent of other risk factors for atherosclerosis. The existence of different GTPCH haplotypes and genetic differences in $\mathrm{BH}_{4}$ availability may therefore be an explanation for the heterogeneity in patients with coronary artery disease. eNOS activity has not only been associated with risk factors for CAD, it may also be of importance in its prevention. Regular aerobic exercise reduces the risk of cardiac events, possibly through shear-stress- 


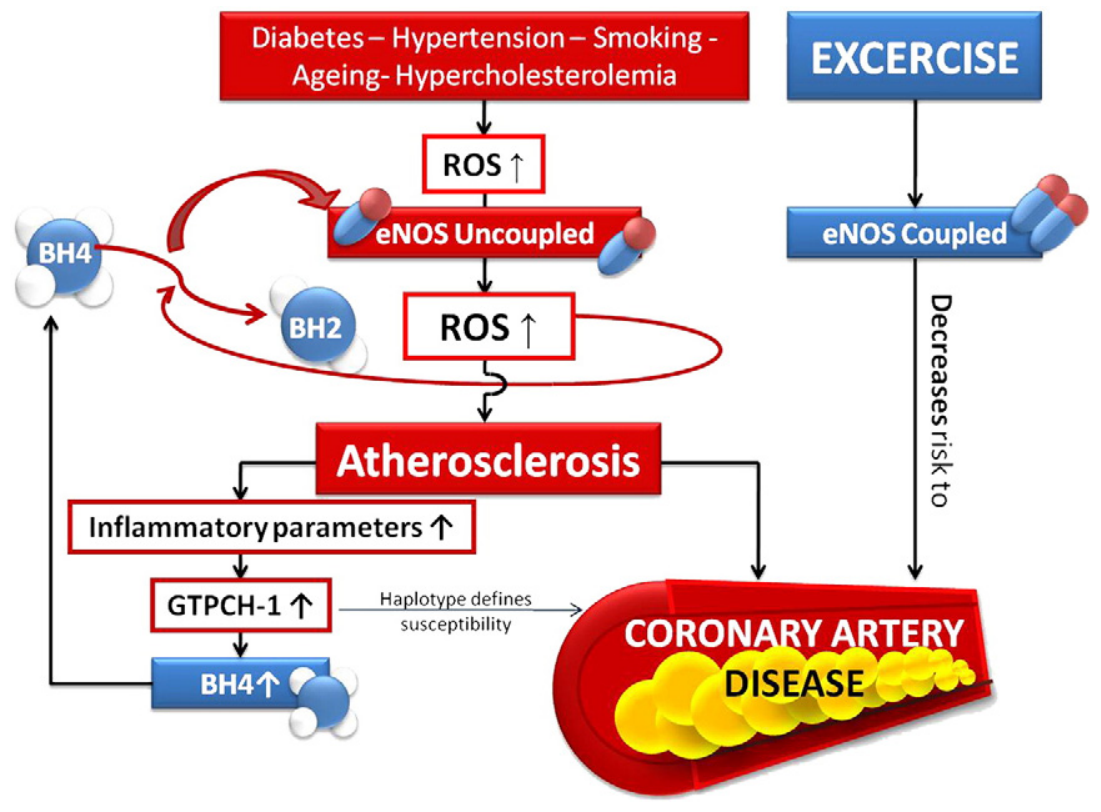

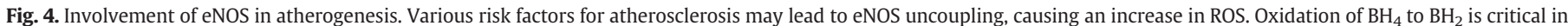

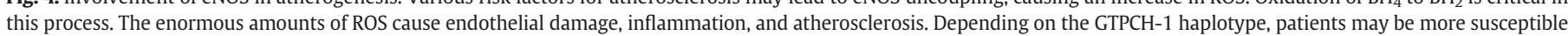
to this mechanism and thus coronary artery disease. Upregulation of GTPCH-1 or external supplements of $\mathrm{BH}_{4}$ may slow this process down or even reverse it.

induced eNOS upregulation and NO production. Regular physical exercise ameliorates peripheral NO-dependent vasodilatation in patients with chronic heart failure [67] and coronary vasomotor activity in CAD patients [68]. Shear stress activates the tyrosine kinase c-Src and initiates an intracellular cascade, which increases eNOS mRNA transcription and stability in vitro [69] through activation of a shear-stress response element on the eNOS promoter. Mice that are heterozygous for c-Src deletion no longer display a positive correlation between training and vascular eNOS expression, indicating that the c-Src pathway is pivotal in how physical training modulates eNOS function [70].

\section{Ischemic heart disease}

Oxidative stress at the cellular level plays a key role in myocardial remodeling after myocardial infarction (MI) $[71,72]$. Previous studies have indicated that cardiac remodeling after MI was attenuated in transgenic mice overexpressing eNOS, but deteriorated in eNOS ${ }^{-/-}$ mice [73]. Similarly, NO can increase angiogenesis [74] and decrease cardiac fibrosis [75] after MI. The presence of eNOS attenuates leftventricular dysfunction and remodeling in a murine model of MI by afterload-independent mechanisms, partially by decreasing myocyte hypertrophy in the myocardium [76]. In addition, Masano et al. [77] demonstrated in a rat model of MI that the ventricular remodeling process after MI was associated with increased superoxide production from the noninfarcted myocardium. Yaoita et al. [78] reported, using a rat model, that an increase in eNOS activity by supplementation of $\mathrm{BH}_{4}$ lowers the myocardial activation of neutrophils after surgically created coronary ligation and subsequent ischemia, protecting both endothelial cells and cardiomyocytes from myocardial inflammation. This was attributed to an eNOS-dependent improvement in coronary arteriole endothelial function and therefore in myocardial perfusion. Consequently, modulating eNOS by administration of $\mathrm{BH}_{4}$ can be considered a potential therapeutic agent to counteract the damaging effect of ischemia through improved coronary perfusion and to attenuate ventricular remodeling and therefore preserve cardiac function. Furthermore, the occurrence and subsequent alleviation of eNOS uncoupling after MI were indicated by a reduction in the eNOS dimer/monomer ratio and its restoration by exogenous $\mathrm{BH}_{4}$ [55]. Supplementation with the $\mathrm{BH}_{4}$ precursor sepiapterin or the synthetic $\mathrm{BH}_{4}$ analogue 6-methyltetrahydropterin both improves response to endothelium-dependent vasodilators in coronary arteries as was demonstrated in vivo in a pig model of coronary occlusion and subsequent reperfusion [79]. However, in another paper by Vasquez-Vivar et al. [30], it was demonstrated that sepiapterin may also uncouple eNOS by antagonizing $\mathrm{BH}_{4}$. Therefore, it may not always work.

\section{Smoking}

Cigarette smoke contains high amounts of radicals such as $\mathrm{NO}, \mathrm{O}_{2}^{-}$, and $\mathrm{ONOO}^{-}$. Reduced availability of $\mathrm{BH}_{4}$ because of oxidation by these radicals may cause eNOS uncoupling and this process, at least in part, contributes to the endothelial damage and dysfunction in chronic smokers. Supplementation of $\mathrm{BH}_{4}$ can improve vasodilatator response in the brachial artery of chronic smokers. However, the mere antioxidant properties of $\mathrm{BH}_{4}$ may also be responsible for this effect. Heitzer et al. [80] found that $\mathrm{BH}_{4}$, but not tetrahydroneopterin (also a reduced pteridine), could modify Acetylcholine-induced changes in forearm blood flow of chronic smokers, which points to a specific effect of $\mathrm{BH}_{4}$ on eNOS rather than its action as a nonspecific antioxidant.

\section{Nitrate tolerance}

Nitrate tolerance is defined as a decline in the vasodilatory effects of nitroglycerin (NTG) after a period of its continuous administration. Oxidative stress in NTG-exposed blood vessels reduces NO bioavailability, resulting not only in compromised relaxation, but also in reduced sensitivity of the vessels to endothelium-dependent vasodilatators. The source of NTG-induced superoxide is still unknown, but uncoupled eNOS is considered to be a potential candidate in addition to components of the mitochondrial respiratory chain and NADPH oxidases. Münzel et al. [81] demonstrated in a model of NTG-treated rats that increased endothelial $\mathrm{O}_{2}^{-}$production is responsible for nitrate tolerance after long-term nitrate treatment. Following these observations they showed that eNOS protein and RNA expression is significantly increased after NTG treatment. In nitrate-tolerant vessels the increased production of ROS was caused by uncoupling of higher 
expressed eNOS and this process depended on phosphorylation by PKC. Ikejima et al. [82] demonstrated significantly reduced $\mathrm{BH}_{4}$ levels possibly leading to eNOS uncoupling in aortic segments obtained from rabbits that had been continuously treated for 7 days with transdermal NTG patches. However, this could not be demonstrated by Schmidt et al. [83] using an established guinea pig model of nitrate tolerance. Furthermore, Gori et al. [84] demonstrated that administration of folic acid can prevent NTG-induced endothelial nitric oxide dysfunction and nitrate tolerance in healthy male volunteers.

\section{Cardiovascular aging}

It is well documented that skeletal muscle vascular conductance and endothelium-dependent vasodilatation are reduced with aging. Aging in rats causes a decline in eNOS activity, which may contribute to the development of hypertension [85]. eNOS uncoupling and a decrease in NO bioavailability may contribute to this aging-related decline in flow-induced vasodilatation and subsequent increase in blood pressure. In humans, a single dose of oral $\mathrm{BH}_{4}$ could restore endothelium-dependent dilatation in the conduit brachial artery of sedentary older men [86]. In addition, Sindler et al. [87] found that age-related reduction in $\mathrm{BH}_{4}$ occurred in conjunction with a decline in flow-induced NO signaling and an increase in superoxide production by eNOS uncoupling. Exercise training prevented this age-related loss of $\mathrm{BH}_{4}$ and improved $\mathrm{NO}$ bioavailability by balancing accelerated $\mathrm{NO}$ and ROS production.

\section{eNOS uncoupling in pulmonary diseases}

\section{Pulmonary artery hypertension}

Chronic hypoxia is one of the main causes of sustained pulmonary artery hypertension (PAH) in patients with chronic obstructive lung disease or congestive heart failure or during cardiopulmonary bypass surgery $[5,88]$. Impairment of NO production is regarded as a possible mechanism in the pathogenesis of $\mathrm{PAH}$ [89], as $\mathrm{eNOS}^{-1-}$ mice are more susceptible to hypoxia than wild-type controls [90]. In rats with hypoxia-induced PAH, eNOS activity, but not eNOS expression, was lowered, indicating that eNOS is inactivated at a posttranslational level. Murata et al. speculated that eNOS inactivation may be caused by a lack of dissociation between eNOS and caveolin-1, inhibiting the translocation of eNOS to the cytosol and impairing Akt-mediated eNOS phosphorylation at Ser1177 [91]. This is in contrast to systemic hypertension, which showed eNOS uncoupling as the critical cause of inactivation of the decrease in the amount of NO produced [27]. In addition, Xu et al. [45] described a decrease in the eNOS substrate L-arginine [45] from increased arginase II activity during PAH. Furthermore, an increase in the endogenous eNOS inhibitor ADMA during PAH has been described [92]. Elevation of ADMA is indeed a potential pathogenetic mechanism for pulmonary hypertension in patients with congenital heart disease [93]. ADMA is mostly elevated in the pulmonary vascular endothelium of PAH patients in areas of intimal fibrotic and plexiform lesions, compared to healthy patients.

\section{Acute lung injury and acute respiratory distress syndrome}

Acute lung injury (ALI) and acute respiratory distress syndrome (ARDS) are acute inflammatory states, which are characterized by a sudden onset of dyspnea, severe hypoxemia, neutrophil pulmonary sequestration, and pulmonary edema secondary to disruption of pulmonary capillary integrity. They remain significant causes of morbidity and mortality in hospitalized patients [94]. Sharma et al. [95] used a lipopolysaccharide (LPS)-induced mouse model of ALI to demonstrate that LPS increases the level of ADMA in endothelial cells. ADMA may be responsible for NOS uncoupling transiently at early stages of ALI. Peak superoxide production occurred $2 \mathrm{~h}$ after exposure to LPS. It was not possible to determine which NOS isoform was predominately responsible for this increase in NOS-derived superoxide. Previously, LPS treatment had been shown to reduce mRNA expression and decrease eNOS protein expression in bovine endothelial cells [96] and $12 \mathrm{~h}$ post-LPS treatment in the mouse lung [97]. As ADMA is associated with eNOS uncoupling [46], it may be possible that eNOS is involved in superoxide and peroxynitrite generation in ALI, leading to protein nitration associated with lung leak in ALI. Peroxynitrite scavengers reduced the nitrated protein levels and decreased capillary leakage. However, further investigation into the individual role of eNOS in ALI is warranted.

Hypoxia associated with proinflammatory mediators in ARDS augments the formation of ROS by increased NADPH oxidase expression. In ARDS an increase in eNOS expression is observed, which may be caused by mechanical ventilation leading to Aktmediated phosphorylation [98]. The concomitant upregulation of eNOS and NADPH oxidase results in increased $\mathrm{ONOO}^{-}$formation and may advance ARDS by promoting tissue damage and inflammation [99]. Therefore, specific antioxidants targeting eNOS uncoupling and/ or its triggers could be an interesting therapeutic approach to ARDS.

\section{eNOS uncoupling during thoracic surgery}

As described above, NO is not only a vasodilator, it also inhibits platelet aggregation, thrombus formation, and smooth muscle cell proliferation and therefore may interfere with cardiovascular outcome. A lack of NO due to eNOS uncoupling may negatively affect postoperative patient outcome. The effects of NO metabolism and eNOS uncoupling have been thoroughly investigated in coronary artery bypass graft surgery (CABG) and lung transplantation.

\section{$C A B G$ surgery}

Conventional stripping of the saphenous vein is associated with more damage to the endothelium and the tunica adventitia and lower eNOS levels in venous endothelium than atraumatic harvesting, by which the surrounding tissue is spared [100]. Impaired NO synthesis due to endothelial damage during graft harvesting may cause early graft failure [101]. Together with an increase in growth factors after ischemia and reperfusion (IR), this diminished NO effect results in neointimal hyperplasia, reduced lumen diameter, and decreased coronary blood flow, which are associated with later stages of graft failure. This may influence the long-term outcome of CABG procedures. Modulating eNOS uncoupling in the cardioplegia solution may also be an adequate approach to preventing CABG failure by endothelial dysfunction. Maintenance of normal NO homeostasis is an important factor in protecting the graft and the heart from IR injury during cardioplegia [102]. Interindividual differences in recuperation from CABG procedure are not dependent on polymorphisms of the eNOS gene, as these do not have any influence on early postoperative hemodynamics after cardiac surgery [103]. Therefore, addition of $\mathrm{BH}_{4}$ and L-arginine may prevent eNOS uncoupling, decrease inflammation, and prevent graft failure [102].

\section{Lung transplantation}

Lung preservation, transplantation, and reperfusion lead to reduced endogenous NO production in lung tissue, indicated by a decreased amount of exhaled NO [104]. Liu et al. [105] investigated the effects of eNOS on lung transplantation surgery in the rat. They demonstrated a reduction in eNOS mRNA during lung transplantation, which was possibly caused by a lower ability of the endothelial and lung epithelial cell to respond appropriately to ischemia and reperfusion. Transplanted lungs had decreased bioavailability of NO. IR may have a direct effect on eNOS synthesis and degradation, contributing to injury in lung transplants. Administration of the NO 
donor NTG prevented reperfusion-induced lung injury such as endothelial injury in alveolar and bronchial epithelial cells in an ex vivo rat lung perfusion model [106]. Administration of the eNOS cofactor $\mathrm{BH}_{4}$ during lung allograft reperfusion in a pig model of lung transplantation reduced posttransplantation lung edema and oxygenderived free radical injury in the graft [107]. Exogenous administration of NO by inhalation from cylinders containing nitrogen for $84 \mathrm{~h}$ on average (15-217 h) after bilateral lung transplantation reduced early severe graft dysfunction, as indicated by a decrease in hypoxia and PAH. Also, these patients needed shorter postoperative mechanical ventilation, had fewer airway complications, and had a decrease in general mortality [108].

\section{Wound healing}

Vasodilation and hyperemia of existing vessels, both NO-mediated processes, are coincident with angiogenesis [109]. Newly formed vessels deliver the necessary metabolic substances to the regenerating tissue to assist wound repair. Closure of the wound is mediated by both wound contraction and wound reepithelialization. The effects of vascular endothelial growth factor (VEGF), one of the key mediators of angiogenesis, are mediated by NO [110]. VEGF upregulates eNOS protein levels and NO production [111], and activation of VEGFR-2 results in upregulation and phosphorylation of eNOS and increased NO production by inducing a peak in intracellular $\mathrm{Ca}^{2+}$ levels [112]. In eNOS $^{-/-}$mice, closure of excisional wounds where a square piece of skin was removed was significantly impaired, and healed cephaladto-caudal incisional wounds developed less tensile strength [113]. This may be of therapeutic importance in such diseases as diabetes mellitus in which a deficit in VEGF expression is part of the associated defect in wound healing [114].

\section{Modulating the eNOS pathway}

\section{L-Arginine}

L-Arginine is the primary substrate for endothelial NO production by eNOS and supplementation can improve endothelial-derived dilatation, decrease adhesion of platelets and monocytes, and reduce systemic and pulmonary artery pressure [115]. A lack of L-arginine may lead to eNOS uncoupling. L-Arginine is broken down by arginases that compete with eNOS for their common substrate [44]. In pulmonary endothelium of patients with pulmonary artery hypertension [45] and in endothelial cells of the corpus cavernosum of diabetes patients [49], arginase expression indeed seems to be upregulated. Therefore, the L-arginine deficiency in endothelial dysfunction can be explained as a very local and relative lack of this amino acid, situated in the direct vicinity of eNOS by an upregulation of L-arginase [49]. This could be a partial explanation of the beneficial effect of L-arginine supplementation observed in some, but not all, clinical studies [116]. In addition, L-arginine can also serve as a direct radical scavenger [117] and compete with the endogenous eNOS inhibitor ADMA [46].

Three days of oral L-arginine administration to young men with CAD showed improvement in endothelium-dependent vasodilatation and reduced monocyte adhesion [118]. In patients with heart failure, oral administration of L-arginine was shown to improve renal function [119], vascular function, and cardiac output [120]. In hypercholesterolemic patients administration of L-arginine improved endotheliumdependent forearm dilatation [121], just as effectively as statin therapy [122]. In addition, some patients with PAH benefit from intravenous infusion of L-arginine, as it increases L-arginine and L-citrulline concentrations and has a potent short-term vasodilating effect, equal to prostacyclin but better tolerated, reducing pulmonary artery pressure [123]. However, most of the positive studies investigating L-arginine supplementation were rather short. In contrast, L-arginine may not be beneficial if given chronically, as shown in the VINTAGE MI study [124]. Nevertheless, this study has been criticized for serious flaws [125]. A meta-analysis concluded that short-term L-arginine treatment improved endothelial function in only those individuals with endothelial dysfunction, as determined with flow-mediated vasodilation [116].

\section{$\mathrm{BH}_{4}$}

$\mathrm{BH}_{4}$ is an FDA-approved therapy for some forms of phenylketonuria, in which there is a deficiency in the hepatic enzyme phenylalanine hydroxylase. Furthermore, $\mathrm{BH}_{4}$ is of critical importance in stabilizing the eNOS dimer, keeping it in coupled form, allowing eNOS to function appropriately. In addition, oral administration of $\mathrm{BH}_{4}$ after acute myocardial infarction induction in rat heart attenuates the remodeling and preserves cardiac function by decreasing superoxide generation [77]. Reduction of the eNOS dimer/monomer ratio after MI in these rats and its restoration by exogenous $\mathrm{BH}_{4}$ indicated the occurrence and subsequent alleviation of eNOS uncoupling. $\mathrm{BH}_{4}$ has been shown to improve endothelial dysfunction in patients with DM 2 [126], heart transplant patients treated with cyclosporine A [127], and patients with inflammatory disorders such as rheumatoid arthritis [128]. $\mathrm{BH}_{4}$ was also found to lower blood pressure [129] but longer term studies have failed to show any significant benefit [130]. $\mathrm{BH}_{4}$ is temperature and light unstable, very hygroscopic, and quickly oxidized, as it is an antioxidant, and therefore difficult in practical use as a chronic drug treatment. The $\mathrm{BH}_{4}$ analogue sapropterin hydrochloride (BioMarin Pharmaceuticals, CA, USA) does not have these stability problems.

\section{Folic acid}

Folic acid has direct superoxide scavenging effects [131] and increases the bioavailability of $\mathrm{BH}_{4}$ in the vasculature by preventing its oxidation [132] and ensuring eNOS coupling. Chronic administration of 5-MTHF, the active form of folic acid, improves endothelial function in patients with systolic heart failure [133], reverses eNOS dysfunction and uncoupling in NTG-treated patients [84], and can restore endothelial function in hypercholesterolemic patients [134]. High-dose folic acid administration to patients with CAD showed no more improved vascular function compared to a low-dose treatment of folic acid [135]. No human data yet are available about the effects of folic acid on myocardial dysfunction.

\section{Other eNOS-modulating agents}

Statins have been reported to increase eNOS stability and its expression on the cell membrane in addition to their well-known LDL-lowering effect [136]. Statins activate adenosine receptors $A_{1}$, $A_{2 A}$, and $A_{2 B}$, which leads to Akt-mediated eNOS phosphorylation [137]. The cardioprotective effects of angiotensin converting enzym inhibitors and angiotensin receptor blockers (ARBs) are also mediated by eNOS-generated NO. ACE inhibitors and ARBs activate eNOS by stimulation of a PI3-kinase/Akt pathway [138]. Both statins and modulators of the rennin-angiotensins system also inhibit NADPH oxidases, potentially resulting in reduced eNOS uncoupling. Estrogens increase eNOS phosphorylation and therefore its activity. This may be an explanation for the lower incidence of atherosclerosis in premenopausal women. Estradiol directly activates eNOS by binding on the estrogen receptor and subsequently activates the cGMPdependent protein kinase $G$ pathway, which phosphorylates the eNOS enzyme [139]. This way, estradiol is a protective agent in IR injury, as was demonstrated in lung tissue after trauma-hemorrhage [140]. A therapeutic possibility for treatment of PAH is sildenafil, which increases pulmonary vasodilatation [141]. Chronic use reduces pulmonary arterial pressure in primary pulmonary hypertension, inhibits 
remodeling of the vessels after hypoxia [142], and also reduces pulmonary hypoxic vasoconstriction in healthy volunteers by raising cGMP [143], as reflected in higher plasma concentrations. Sildenafil synergistically enhances the effectiveness of NO inhalation because they both raise cGMP levels, as shown by a longer lasting and quantitatively higher pulmonary vasodilatation, in both ventricular insufficiency and pulmonary arterial hypertension. High doses of vitamin $C$ can acutely improve endothelial dysfunction. Its antioxidant effects stabilize $\mathrm{BH}_{4}$, reducing the formation of its oxidation product $\mathrm{BH}_{2}$ [144], and facilitate the recycling of $\mathrm{BH}_{4}$, independent of superoxide scavenging [39]. Another eNOS modulator is AVE9488, a so-called eNOS enhancer, which may serve as a new cardioprotectant, as it improves left-ventricular remodeling and function and diminishes endothelial dysfunction after experimental MI in rodents $[145,146]$. No clinical data from AVE9488 are available yet.

\section{Conclusion}

During the past few years, eNOS uncoupling, and especially eNOSdependent superoxide generation, has been suggested as having a major role in the pathogenesis of many cardiovascular and pulmonary diseases, such as systemic and pulmonary artery hypertension, heart failure, and ischemia/reperfusion injury. More research is needed to further explore the triggers (i.e., sources of superoxide) that initiate eNOS uncoupling. The possibility of targeting specific sources of ROS has paved the way for various new therapeutic approaches. Recent data have shown that by specifically targeting eNOS-dependent ROS generation, eNOS uncoupling can not only be prevented but also be reversed. Modulating eNOS uncoupling by eNOS modulators such as $\mathrm{BH}_{4}$ and folic acid has been proven to be effective in the human vasculature. More focused research is needed to extrapolate the interesting preclinical data on these eNOS modulators to the human myocardium and lung.

\section{Acknowledgments}

This research was supported by the dutch heart foundation, NWOVidi/Aspasia (both to ALM), NHMRC Australia, EU Marie-Curie IRG (both HHS) and the Flemisch Foundation against Cancer (to PES).

\section{References}

[1] Furchgott, R. F.; Zawadski, J. V. The obligatory role of endothelial cells in the relaxation of arterial smooth muscle by acetylcholine. Nature 288:373-376; 1980.

[2] Palmer, R. M.; Ferrige, A. G.; Moncada, S. Nitric oxide release accounts for the biological activity of endothelium-derived relaxing factor. Nature 327:524-526; 1987.

[3] Schmidt, H. H.; Nau, H.; Wittfoht, W.; Gerlach, J.; Prescher, K. E.; Klein, M. M.; Niroomand, F. Bohme, E. Arginine is a physiological precursor of endotheliumderived nitric oxide. Eur. J. Pharmacol. 154:213-216; 1988.

[4] Wei, C.; Jiang, S.; Lust, J. A.; Daly, R. C.; McGregor, C. G. Genetic expression of endothelial nitric oxide synthase in human atrial myocardium. Mayo Clin. Proc. 71:346-350; 1996

[5] Giaid, A.; Saleh, D. Reduced expression of endothelial nitric oxide synthase in the lungs of patients with pulmonary hypertension. N. Engl. J. Med. 333:214-221; 1995.

[6] Tracey, W. R.; Pollock, J. S.; Murad, F.; Nakane, M.; Forstermann, U. Identification of an endothelial-like type III NO synthase in LLC-PK1 kidney epithelial cells. Am. J. Physiol. 266:C22-C28; 1994.

[7] Vanhoutte, P. M. How we learned to say NO. Arterioscler. Thromb. Vasc. Biol. 29 1156-1160; 2009.

[8] Reif, A.; Frohlich, L. G.; Kotsonis, P.; Frey, A.; Bommel, H. M.; Wink, D. A. Pfleiderer, W.; Schmidt, H. H. Tetrahydrobiopterin inhibits monomerization and is consumed during catalysis in neuronal NO synthase. J. Biol. Chem. 274: 24921-24929; 1999.

[9] Venema, R. C.; Ju, H.; Zou, R.; Ryan, J. W.; Venema, V. J. Subunit interactions of endothelial nitric-oxide synthase: comparisons to the neuronal and inducible nitric-oxide synthase isoforms. J. Biol. Chem. 272:1276-1282; 1997.

[10] Klatt, P.; Pfeiffer, S.; List, B. M.; Lehner, D.; Glatter, O.; Bachinger, H. P.; Werner, E. R.; Schmidt, K.; Mayer, B. Characterization of heme-deficient neuronal nitricoxide synthase reveals a role for heme in subunit dimerization and binding of the amino acid substrate and tetrahydrobiopterin. J. Biol. Chem. 271:7336-7342; 1996.

[11] Raman, C. S.; Li, H.; Martasek, P.; Kral, V.; Masters, B. S.; Poulos, T. L. Crystal structure of constitutive endothelial nitric oxide synthase: a paradigm for pterin function involving a novel metal center. Cell 95:939-950; 1998.

[12] Hemmens, B.; Mayer, B. Enzymology of nitric oxide synthases. Meth. Mol. Biol. 100:1-32; 1998.

[13] Nishida, C. R.; Ortiz de Montellano, P. R. Electron transfer and catalytic activity of nitric oxide synthases: chimeric constructs of the neuronal, inducible, and endothelial isoforms. J. Biol. Chem. 273:5566-5571; 1998.

[14] Andrew, P. J.; Mayer, B. Enzymatic function of nitric oxide synthases. Cardiovasc. Res. 43:521-531; 1999.

[15] Flam, B. R.; Hartmann, P. J.; Harrell-Booth, M.; Solomonson, L. P.; Eichler, D. C. Caveolar localization of arginine regeneration enzymes, argininosuccinate synthase, and lyase, with endothelial nitric oxide synthase. Nitric Oxide 5:187-197; 2001.

[16] Goodwin, B. L.; Solomonson, L. P.; Eichler, D. C. Argininosuccinate synthase expression is required to maintain nitric oxide production and cell viability in aortic endothelial cells. J. Biol. Chem. 279:18353-18360; 2004.

[17] Solomonson, L. P.; Flam, B. R.; Pendleton, L. C.; Goodwin, B. L.; Eichler, D. C. The caveolar nitric oxide synthase/arginine regeneration system for NO production in endothelial cells. J. Exp. Biol. 206:2083-2087; 2003.

[18] Butt, E.; Bernhardt, M.; Smolenski, A.; Kotsonis, P.; Frohlich, L. G.; Sickmann, A. Meyer, H. E.; Lohmann, S. M.; Schmidt, H. H. Endothelial nitric-oxide synthase (type III) is activated and becomes calcium independent upon phosphorylation by cyclic nucleotide-dependent protein kinases. J. Biol. Chem. 275:5179-5187; 2000.

[19] McCabe, T. J.; Fulton, D.; Roman, L. J.; Sessa, W. C. Enhanced electron flux and reduced calmodulin dissociation may explain "calcium-independent" eNOS activation by phosphorylation. J. Biol. Chem. 275:6123-6128; 2000.

[20] Chen, C. A.; Druhan, L. J.; Varadharaj, S.; Chen, Y. R.; Zweier, J. L. Phosphorylation of endothelial nitric-oxide synthase regulates superoxide generation from the enzyme. J. Biol. Chem. 283:27038-27047; 2008.

[21] Schulz, E.; Anter, E.; Zou, M. H.; Keaney Jr., J. F. Estradiol-mediated endothelial nitric oxide synthase association with heat shock protein 90 requires adenosine monophosphate-dependent protein kinase. Circulation 111:3473-3480; 2005.

22] Fleming I. Fisslthaler, B. Dimmeler, S.; Kemp, B. E.: Busse, R. Phosphorylation of $\operatorname{Thr}(495)$ regulates $\mathrm{Ca}(2+) /$ calmodulin-dependent endothelial nitric oxide synthase activity. Circ. Res. 88:E68-E75; 2001.

[23] Mount, P. F.; Kemp, B. E.; Power, D. A. Regulation of endothelial and myocardial NO synthesis by multi-site eNOS phosphorylation. J. Mol. Cell. Cardiol. 42: 271-279; 2007.

[24] Gorren, A. C.; Schrammel, A.; Schmidt, K.; Mayer, B. Effects of pH on the structure and function of neuronal nitric oxide synthase. Biochem. J. 331 (Pt 3):801-807; 1998.

[25] Kotsonis, P.; Frohlich, L. G.; Shutenko, Z. V.; Horejsi, R.; Pfleiderer, W.; Schmidt, H. H. Allosteric regulation of neuronal nitric oxide synthase by tetrahydrobiopterin and suppression of auto-damaging superoxide. Biochem. J. 346 (Pt 3): 767-776; 2000.

[26] Panda, K.; Rosenfeld, R. J.; Ghosh, S.; Meade, A. L.; Getzoff, E. D.; Stuehr, D. J. Distinct dimer interaction and regulation in nitric-oxide synthase types I, II, and III. J. Biol. Chem. 277:31020-31030; 2002.

[27] Landmesser, U.; Dikalov, S.; Price, S. R.; McCann, L.; Fukai, T.; Holland, S. M.; Mitch, W. E.; Harrison, D. G. Oxidation of tetrahydrobiopterin leads to uncoupling of endothelial cell nitric oxide synthase in hypertension. J. Clin. Invest. 111:1201-1209; 2003.

[28] Vasquez-Vivar, J.; Kalyanaraman, B.; Martasek, P. The role of tetrahydrobiopterin in superoxide generation from eNOS: enzymology and physiological implications. Free Radic. Res. 37:121-127; 2003.

[29] Shi, W.; Meininger, C. J.; Haynes, T. E.; Hatakeyama, K.; Wu, G. Regulation of tetrahydrobiopterin synthesis and bioavailability in endothelial cells. Cell Biochem. Biophys. 41:415-434; 2004.

[30] Vasquez-Vivar, J.; Martasek, P.; Whitsett, J.; Joseph, J.; Kalyanaraman, B. The ratio between tetrahydrobiopterin and oxidized tetrahydrobiopterin analogues controls superoxide release from endothelial nitric oxide synthase: an EPR spin trapping study. Biochem. J. 362:733-739; 2002.

[31] Gesierich, A.; Niroomand, F.; Tiefenbacher, C. P. Role of human GTP cyclohydrolase I and its regulatory protein in tetrahydrobiopterin metabolism. Basic Res. Cardiol. 98:69-75; 2003.

[32] Hattori, Y.; Nakanishi, N.; Kasai, K.; Shimoda, S. I. GTP cyclohydrolase I mRNA induction and tetrahydrobiopterin synthesis in human endothelial cells. Biochim. Biophys. Acta 1358:61-66; 1997.

[33] Peterson, T. E.; d'Uscio, L. V.; Cao, S.; Wang, X. L.; Katusic, Z. S. Guanosine triphosphate cyclohydrolase I expression and enzymatic activity are present in caveolae of endothelial cells. Hypertension 53:189-195; 2009.

[34] Antoniades, C.; Shirodaria, C.; Van, A. T.; Cunnington, C.; Tegeder, I.; Lotsch, J.; Guzik, T. J.; Leeson, P.; Diesch, J.; Tousoulis, D.; Stefanadis, C.; Costigan, M.; Woolf, C. J.; Alp, N. J.; Channon, K. M. GCH1 haplotype determines vascular and plasma biopterin availability in coronary artery disease effects on vascular superoxide production and endothelial function. J. Am. Coll. Cardiol. 52: 158-165; 2008.

[35] Blau, N.; Bonafe, L.; Thony, B. Tetrahydrobiopterin deficiencies without hyperphenylalaninemia: diagnosis and genetics of dopa-responsive dystonia and sepiapterin reductase deficiency. Mol. Genet. Metab. 74:172-185; 2001.

[36] McMillan, K.; Adler, M.; Auld, D. S.; Baldwin, J. J.; Blasko, E.; Browne, L. J.; Chelsky, D.; Davey, D.; Dolle, R. E.; Eagen, K. A.; Erickson, S.; Feldman, R. I.; Glaser, C. B.; Mallari, C.; Morrissey, M. M.; Ohlmeyer, M. H.; Pan, G.; Parkinson, J. F.; Phillips, 
G. B.; Polokoff, M. A.; Sigal, N. H.; Vergona, R.; Whitlow, M.; Young, T. A.; Devlin, J. J. Allosteric inhibitors of inducible nitric oxide synthase dimerization discovered via combinatorial chemistry. Proc. Natl Acad. Sci. USA 97:1506-1511; 2000.

[37] Beckman, J. S.; Koppenol, W. H. Nitric oxide, superoxide, and peroxynitrite: the good, the bad, and ugly. Am. J. Physiol. 271:C1424-C1437; 1996.

[38] Szabo, C. Multiple pathways of peroxynitrite cytotoxicity. Toxicol. Lett. 140-141: 105-112; 2003.

[39] Kuzkaya, N.; Weissmann, N.; Harrison, D. G.; Dikalov, S. Interactions of peroxynitrite, tetrahydrobiopterin, ascorbic acid, and thiols: implications for uncoupling endothelial nitric-oxide synthase. J. Biol. Chem. 278:22546-22554; 2003.

[40] Bendall, J. K.; Alp, N. J.; Warrick, N.; Cai, S.; Adlam, D.; Rockett, K.; Yokoyama, M.; Kawashima, S.; Channon, K. M. Stoichiometric relationships between endothelial tetrahydrobiopterin, endothelial NO synthase (eNOS) activity, and eNOS coupling in vivo: insights from transgenic mice with endothelial-targeted GTP cyclohydrolase 1 and eNOS overexpression. Circ. Res. 97:864-871; 2005.

[41] Crabtree, M. J.; Tatham, A. L.; Hale, A. B.; Alp, N. J.; Channon, K. M. Critical role for tetrahydrobiopterin recycling by dihydrofolate reductase in regulation of endothelial nitric-oxide synthase coupling: relative importance of the de novo biopterin synthesis versus salvage pathways. J. Biol. Chem. 284:28128-28136; 2009.

[42] Heiss, E. H.; Schachner, D.; Werner, E. R.; Dirsch, V. M. Active NF-E2-related factor (Nrf2) contributes to keep endothelial NO synthase (eNOS) in the coupled state: role of reactive oxygen species (ROS), eNOS, and heme oxygenase (HO-1) levels. J. Biol. Chem. 284:31579-31586; 2009.

[43] Simon, A.; Plies, L.; Habermeier, A.; Martine, U.; Reining, M.; Closs, E. I. Role of neutral amino acid transport and protein breakdown for substrate supply of nitric oxide synthase in human endothelial cells. Circ. Res. 93:813-820; 2003.

[44] Bachetti, T.; Comini, L.; Francolini, G.; Bastianon, D.; Valetti, B.; Cadei, M. Grigolato, P.; Suzuki, H.; Finazzi, D.; Albertini, A.; Curello, S.; Ferrari, R. Arginase pathway in human endothelial cells in pathophysiological conditions. J. Mol. Cell. Cardiol. 37:515-523; 2004

[45] Xu, W.; Kaneko, F. T.; Zheng, S.; Comhair, S. A.; Janocha, A. J.; Goggans, T.; Thunnissen, F. B.; Farver, C.; Hazen, S. L.; Jennings, C.; Dweik, R. A.; Arroliga, A. C.; Erzurum, S. C. Increased arginase II and decreased NO synthesis in endothelial cells of patients with pulmonary arterial hypertension. FASEB J. 18:1746-1748; 2004.

[46] Antoniades, C.; Shirodaria, C.; Leeson, P.; Antonopoulos, A.; Warrick, N.; VanAssche, T.; Cunnington, C.; Tousoulis, D.; Pillai, R.; Ratnatunga, C.; Stefanadis, C.; Channon, K. M. Association of plasma asymmetrical dimethylarginine (ADMA) with elevated vascular superoxide production and endothelial nitric oxide synthase uncoupling: implications for endothelial function in human atherosclerosis. Eur. Heart J. 30:1142-1150; 2009.

[47] Sydow, K.; Munzel, T. ADMA and oxidative stress. Atheroscler. Suppl. 4:41-51; 2003

[48] Druhan, L. J.; Forbes, S. P.; Pope, A. J.; Chen, C. A.; Zweier, J. L.; Cardounel, A. J. Regulation of eNOS-derived superoxide by endogenous methylarginines. Biochemistry 47:7256-7263; 2008.

[49] Forstermann, U.; Munzel, T. Endothelial nitric oxide synthase in vascular disease: from marvel to menace. Circulation 113:1708-1714; 2006.

[50] Chen, W.; Druhan, L. J.; Chen, C. A.; Hemann, C.; Chen, Y. R.; Berka, V.; Tsai, A. L.; Zweier, J. L. Peroxynitrite induces destruction of the tetrahydrobiopterin and heme in endothelial nitric oxide synthase: transition from reversible to irreversible enzyme inhibition. Biochemistry 49:3129-3137; 2010.

[51] Huang, P. L.; Huang, Z.; Mashimo, H.; Bloch, K. D.; Moskowitz, M. A.; Bevan, J. A.; Fishman, M. C. Hypertension in mice lacking the gene for endothelial nitric oxide synthase. Nature 377:239-242; 1995.

[52] Mollnau, H.; Wendt, M.; Szocs, K.; Lassegue, B.; Schulz, E.; Oelze, M.; Li, H.; Bodenschatz, M.; August, M.; Kleschyov, A. L.; Tsilimingas, N.; Walter, U.; Forstermann, U.; Meinertz, T.; Griendling, K.; Munzel, T. Effects of angiotensin II infusion on the expression and function of $\mathrm{NAD}(\mathrm{P}) \mathrm{H}$ oxidase and components of nitric oxide/cGMP signaling. Circ. Res. 90:E58-E65; 2002.

[53] Ohashi, Y.; Kawashima, S.; Hirata, K.; Yamashita, T.; Ishida, T.; Inoue, N.; Sakoda, T.; Kurihara, H.; Yazaki, Y.; Yokoyama, M. Hypotension and reduced nitric oxideelicited vasorelaxation in transgenic mice overexpressing endothelial nitric oxide synthase. J. Clin. Invest. 102:2061-2071; 1998.

[54] Takimoto, E.; Champion, H. C.; Li, M.; Ren, S.; Rodriguez, E. R.; Tavazzi, B.; Lazzarino, G.; Paolocci, N.; Gabrielson, K. L.; Wang, Y.; Kass, D. A. Oxidant stress from nitric oxide synthase-3 uncoupling stimulates cardiac pathologic remodeling from chronic pressure load. J. Clin. Invest. 115:1221-1231; 2005.

[55] Moens, A. L.; Takimoto, E.; Tocchetti, C. G.; Chakir, K.; Bedja, D.; Cormaci, G.; Ketner, E. A.; Majmudar, M.; Gabrielson, K.; Halushka, M. K.; Mitchell, J. B.; Biswal, S.; Channon, K. M.; Wolin, M. S.; Alp, N. J.; Paolocci, N.; Champion, H. C.; Kass, D. A. Reversal of cardiac hypertrophy and fibrosis from pressure overload by tetrahydrobiopterin: efficacy of recoupling nitric oxide synthase as a therapeutic strategy. Circulation 117:2626-2636; 2008.

[56] Zou, M. H.; Shi, C.; Cohen, R. A. Oxidation of the zinc-thiolate complex and uncoupling of endothelial nitric oxide synthase by peroxynitrite. J. Clin. Invest. 109:817-826; 2002

[57] Hink, U.; Li, H.; Mollnau, H.; Oelze, M.; Matheis, E.; Hartmann, M.; Skatchkov, M.; Thaiss, F.; Stahl, R. A.; Warnholtz, A.; Meinertz, T.; Griendling, K.; Harrison, D. G.; Forstermann, U.; Munzel, T. Mechanisms underlying endothelial dysfunction in diabetes mellitus. Circ. Res. 88:E14-E22; 2001.

[58] Pennathur, S.; Wagner, J. D.; Leeuwenburgh, C.; Litwak, K. N.; Heinecke, J. W. A hydroxyl radical-like species oxidizes Cynomolgus monkey artery wall proteins in early diabetic vascular disease. J. Clin. Invest. 107:853-860; 2001.
[59] Cai, S.; Khoo, J.; Mussa, S.; Alp, N. J.; Channon, K. M. Endothelial nitric oxide synthase dysfunction in diabetic mice: importance of tetrahydrobiopterin in eNOS dimerisation. Diabetologia 48:1933-1940; 2005.

[60] Shinozaki, K.; Kashiwagi, A.; Nishio, Y.; Okamura, T.; Yoshida, Y.; Masada, M.; Toda, N.; Kikkawa, R. Abnormal biopterin metabolism is a major cause of impaired endothelium-dependent relaxation through nitric oxide $/ \mathrm{O}_{2}^{-}$imbalance in insulin-resistant rat aorta. Diabetes 48:2437-2445; 1999.

[61] Wenzel, P.; Daiber, A.; Oelze, M.; Brandt, M.; Closs, E.; Xu, J.; Thum, T.; Bauersachs, J.; Ertl, G.; Zou, M. H.; Forstermann, U.; Munzel, T. Mechanisms underlying recoupling of eNOS by HMG-CoA reductase inhibition in a rat mode of streptozotocin-induced diabetes mellitus. Atherosclerosis 198:65-76; 2008.

[62] Thum, T.; Fraccarollo, D.; Schultheiss, M.; Froese, S.; Galuppo, P.; Widder, J. D. Tsikas, D.; Ertl, G.; Bauersachs, J. Endothelial nitric oxide synthase uncoupling impairs endothelial progenitor cell mobilization and function in diabetes. Diabetes 56:666-674; 2007.

[63] Wang, S.; Xu, J.; Song, P.; Viollet, B.; Zou, M. H. In vivo activation of AMPactivated protein kinase attenuates diabetes-enhanced degradation of GTP cyclohydrolase I. Diabetes 58:1893-1901; 2009.

[64] Oelze, M.; Mollnau, H.; Hoffmann, N.; Warnholtz, A.; Bodenschatz, M. Smolenski, A.; Walter, U.; Skatchkov, M.; Meinertz, T.; Munzel, T. Vasodilatorstimulated phosphoprotein serine 239 phosphorylation as a sensitive monitor of defective nitric oxide/cGMP signaling and endothelial dysfunction. Circ. Res. 87: 999-1005; 2000

[65] Antoniades, C.; Shirodaria, C.; Crabtree, M.; Rinze, R.; Alp, N.; Cunnington, C.; Diesch, J.; Tousoulis, D.; Stefanadis, C.; Leeson, P.; Ratnatunga, C.; Pillai, R.; Channon, K. M. Altered plasma versus vascular biopterins in human atherosclerosis reveal relationships between endothelial nitric oxide synthase coupling, endothelial function, and inflammation. Circulation 116:2851-2859; 2007.

[66] Lotsch, J.; Belfer, I.; Kirchhof, A.; Mishra, B. K.; Max, M. B.; Doehring, A.; Costigan, M.; Woolf, C. J.; Geisslinger, G.; Tegeder, I. Reliable screening for a painprotective haplotype in the GTP cyclohydrolase 1 gene (GCH1) through the use of 3 or fewer single nucleotide polymorphisms. Clin. Chem. 53:1010-1015; 2007.

[67] Hornig, B.; Maier, V.; Drexler, H. Physical training improves endothelial function in patients with chronic heart failure. Circulation 93:210-214; 1996.

[68] Hambrecht, R.; Wolf, A.; Gielen, S.; Linke, A.; Hofer, J.; Erbs, S.; Schoene, N.; Schuler, G. Effect of exercise on coronary endothelial function in patients with coronary artery disease. N. Engl. J. Med. 342:454-460; 2000.

[69] Davis, M. E.; Cai, H.; Drummond, G. R.; Harrison, D. G. Shear stress regulates endothelial nitric oxide synthase expression through c-Src by divergent signaling pathways. Circ. Res. 89:1073-1080; 2001.

[70] Davis, M. E.; Cai, H.; McCann, L.; Fukai, T.; Harrison, D. G. Role of c-Src in regulation of endothelial nitric oxide synthase expression during exercise training. Am. J. Physiol. Heart Circ. Physiol. 284:H1449-H1453; 2003.

[71] Sawyer, D. B.; Siwik, D. A.; Xiao, L.; Pimentel, D. R.; Singh, K.; Colucci, W. S. Role of oxidative stress in myocardial hypertrophy and failure. J. Mol. Cell. Cardiol. 34: 379-388; 2002.

[72] Tsutsui, H. Novel pathophysiological insight and treatment strategies for heart failure-lessons from mice and patients. Circ. J. 68:1095-1103; 2004.

[73] Jones, S. P.; Greer, J. J.; van, H. R.; Duncker, D. J.; de, C. R.; Lefer, D. J. Endothelial nitric oxide synthase overexpression attenuates congestive heart failure in mice. Proc. Natl. Acad. Sci. USA 100:4891-4896; 2003.

[74] Murohara, T.; Asahara, T.; Silver, M.; Bauters, C.; Masuda, H.; Kalka, C.; Kearney, M.; Chen, D.; Symes, J. F.; Fishman, M. C.; Huang, P. L.; Isner, J. M. Nitric oxide synthase modulates angiogenesis in response to tissue ischemia. J. Clin. Invest 101:2567-2578; 1998.

[75] Kim, N. N.; Villegas, S.; Summerour, S. R.; Villarreal, F. J. Regulation of cardiac fibroblast extracellular matrix production by bradykinin and nitric oxide. J. Mol. Cell. Cardiol. 31:457-466; 1999.

[76] Scherrer-Crosbie, M.; Ullrich, R.; Bloch, K. D.; Nakajima, H.; Nasseri, B.; Aretz, H. T.; Lindsey, M. L.; Vancon, A. C.; Huang, P. L.; Lee, R. T.; Zapol, W. M.; Picard, M. H. Endothelial nitric oxide synthase limits left ventricular remodeling after myocardial infarction in mice. Circulation 104:1286-1291; 2001.

[77] Masano, T.; Kawashima, S.; Toh, R.; Satomi-Kobayashi, S.; Shinohara, M.; Takaya, T.; Sasaki, N.; Takeda, M.; Tawa, H.; Yamashita, T.; Yokoyama, M.; Hirata, K. Beneficial effects of exogenous tetrahydrobiopterin on left ventricular remodeling after myocardial infarction in rats: the possible role of oxidative stress caused by uncoupled endothelial nitric oxide synthase. Circ. J. 72:1512-1519; 2008

[78] Yaoita, H.; Yoshinari, K.; Maehara, K.; Sando, M.; Watanabe, K.; Maruyama, Y. Different effects of a high-cholesterol diet on ischemic cardiac dysfunction and remodeling induced by coronary stenosis and coronary occlusion. J. Am. Coll. Cardiol. 45:2078-2087; 2005.

[79] Tiefenbacher, C. P.; Chilian, W. M.; Mitchell, M.; DeFily, D. V. Restoration of endothelium-dependent vasodilation after reperfusion injury by tetrahydrobiopterin. Circulation 94:1423-1429; 1996.

[80] Heitzer, T.; Brockhoff, C.; Mayer, B.; Warnholtz, A.; Mollnau, H.; Henne, S.; Meinertz, T.; Munzel, T. Tetrahydrobiopterin improves endothelium-dependent vasodilation in chronic smokers: evidence for a dysfunctional nitric oxide synthase. Circ. Res. 86:E36-E41; 2000.

[81] Munzel, T.; Li, H.; Mollnau, H.; Hink, U.; Matheis, E.; Hartmann, M.; Oelze, M.; Skatchkov, M.; Warnholtz, A.; Duncker, L.; Meinertz, T.; Forstermann, U. Effects of long-term nitroglycerin treatment on endothelial nitric oxide synthase (NOS III) gene expression, NOS III-mediated superoxide production, and vascular NO bioavailability. Circ. Res. 86:E7-E12; 2000.

[82] Ikejima, H.; Imanishi, T.; Tsujioka, H.; Kuroi, A.; Muragaki, Y.; Mochizuki, S.; Goto M.; Yoshida, K.; Akasaka, T. Effect of pioglitazone on nitroglycerin-induced 
impairment of nitric oxide bioavailability by a catheter-type nitric oxide sensor. Circ. J. 72:998-1002; 2008.

[83] Schmidt, K.; Rehn, M.; Stessel, H.; Wolkart, G.; Mayer, B. Evidence against tetrahydrobiopterin depletion of vascular tissue exposed to nitric oxide/ superoxide or nitroglycerin. Free Radic. Biol. Med. 48:145-152; 2010.

[84] Gori, T.; Burstein, J. M.; Ahmed, S.; Miner, S. E.; Al-Hesayen, A.; Kelly, S.; Parker, J. D. Folic acid prevents nitroglycerin-induced nitric oxide synthase dysfunction and nitrate tolerance: a human in vivo study. Circulation 104:1119-1123; 2001

[85] Chou, T. C.; Yen, M. H.; Li, C. Y.; Ding, Y. A. Alterations of nitric oxide synthase expression with aging and hypertension in rats. Hypertension 31:643-648; 1998.

[86] Eskurza, I.; Myerburgh, L. A.; Kahn, Z. D.; Seals, D. R. Tetrahydrobiopterin augments endothelium-dependent dilatation in sedentary but not in habitually exercising older adults. J. Physiol. 568:1057-1065; 2005.

[87] Sindler, A. L.; Delp, M. D.; Reyes, R.; Wu, G.; Muller-Delp, J. M. Effects of ageing and exercise training on eNOS uncoupling in skeletal muscle resistance arterioles. J. Physiol. 587:3885-3897; 2009.

[88] Xue, C.; Johns, R. A. Endothelial nitric oxide synthase in the lungs of patients with pulmonary hypertension. N. Engl. J. Med. 333:1642-1644; 1995.

[89] Veyssier-Belot, C.; Cacoub, P. Role of endothelial and smooth muscle cells in the physiopathology and treatment management of pulmonary hypertension. Cardiovasc. Res. 44:274-282; 1999.

[90] Fagan, K. A.; Fouty, B. W.; Tyler, R. C.; Morris Jr., K. G.; Hepler, L. K.; Sato, K.; LeCras, T. D.; Abman, S. H.; Weinberger, H. D.; Huang, P. L.; McMurtry, I. F.; Rodman, D. M. The pulmonary circulation of homozygous or heterozygous eNOS-null mice is hyperresponsive to mild hypoxia. J. Clin. Invest. 103:291-299; 1999.

[91] Murata, T.; Sato, K.; Hori, M.; Ozaki, H.; Karaki, H. Decreased endothelial nitricoxide synthase (eNOS) activity resulting from abnormal interaction between eNOS and its regulatory proteins in hypoxia-induced pulmonary hypertension. J. Biol. Chem. 277:44085-44092; 2002.

[92] Sud, N.; Wells, S. M.; Sharma, S.; Wiseman, D. A.; Wilham, J.; Black, S. M. Asymmetric dimethylarginine inhibits HSP90 activity in pulmonary arterial endothelial cells: role of mitochondrial dysfunction. Am. J. Physiol. Cell Physiol. 294:C1407-C1418; 2008

[93] Gorenflo, M.; Zheng, C.; Werle, E.; Fiehn, W.; Ulmer, H. E. Plasma levels of asymmetrical dimethyl-L-arginine in patients with congenital heart disease and pulmonary hypertension. J. Cardiovasc. Pharmacol. 37:489-492; 2001.

[94] Martinez, O.; Nin, N.; Esteban, A. Prone position for the treatment of acute respiratory distress syndrome: a review of current literature. Arch. Bronconeumol. 45:291-296; 2009.

[95] Sharma, S.; Kumar, S.; Wiseman, D. A.; Kallarackal, S.; Ponnala, S.; Elgaish, M.; Tian, J.; Fineman, J. R.; Black, S. M. Perinatal changes in superoxide generation in the ovine lung: alterations associated with increased pulmonary blood flow. Vasc. Pharmacol. 53:38-52; 2010.

[96] Lu, J. L.; Schmiege III, L. M.; Kuo, L.; Liao, J. C. Downregulation of endothelial constitutive nitric oxide synthase expression by lipopolysaccharide. Biochem. Biophys. Res. Commun. 225:1-5; 1996.

[97] Chatterjee, A.; Snead, C.; Yetik-Anacak, G.; Antonova, G.; Zeng, J.; Catravas, J. D. Heat shock protein 90 inhibitors attenuate LPS-induced endothelial hyperpermeability. Am. J. Physiol. Lung Cell. Mol. Physiol. 294:L755-L763; 2008.

[98] Li, L. F.; Liao, S. K.; Lee, C. H.; Huang, C. C.; Quinn, D. A. Involvement of Akt and endothelial nitric oxide synthase in ventilation-induced neutrophil infiltration: a prospective, controlled animal experiment. Crit. Care 11:R89; 2007.

[99] Muzaffar, S.; Shukla, N.; Angelini, G. D.; Jeremy, J. Y. Prednisolone augments superoxide formation in porcine pulmonary artery endothelial cells through differential effects on the expression of nitric oxide synthase and NADPH oxidase. Br. J. Pharmacol. 145:688-697; 2005.

[100] Dashwood, M. R.; Savage, K.; Dooley, A.; Shi-Wen, X.; Abraham, D. J.; Souza, D. S. Effect of vein graft harvesting on endothelial nitric oxide synthase and nitric oxide production. Ann. Thorac. Surg. 80:939-944; 2005.

[101] Johansson, B. L.; Souza, D. S.; Bodin, L.; Filbey, D.; Bojo, L. No touch vein harvesting technique for CABG improves the long-term clinical outcome. Scand. Cardiovasc. J. 43:63-68; 2009.

[102] Podesser, B. K.; Hallstrom, S. Nitric oxide homeostasis as a target for drug additives to cardioplegia. Br. J. Pharmacol. 151:930-940; 2007.

[103] Liakopoulos, O. J.; Dorge, H.; Popov, A. F.; Schmitto, J. D.; Cattaruzza, M. Schoendube, F. A. Influence of eNOS gene polymorphisms (894G/T; - 786C/T) on postoperative hemodynamics after cardiac surgery. Thorac. Cardiovasc. Surg. 54:233-238; 2006

[104] Marczin, N.; Riedel, B.; Gal, J.; Polak, J.; Yacoub, M. Exhaled nitric oxide during lung transplantation. Lancet 350:1681-1682; 1997.

[105] Liu, M.; Tremblay, L.; Cassivi, S. D.; Bai, X. H.; Mourgeon, E.; Pierre, A. F.; Slutsky, A. S.; Post, M.; Keshavjee, S. Alterations of nitric oxide synthase expression and activity during rat lung transplantation. Am. J. Physiol. Lung Cell. Mol. Physiol. 278: L1071-L1081; 2000.

[106] Kawashima, M.; Bando, T.; Nakamura, T.; Isowa, N.; Liu, M.; Toyokuni, S.; Hitomi, S.; Wada, H. Cytoprotective effects of nitroglycerin in ischemia-reperfusioninduced lung injury. Am. J. Respir. Crit. Care Med. 161:935-943; 2000.

[107] Schmid, R. A.; Hillinger, S.; Walter, R.; Zollinger, A.; Stammberger, U.; Speich, R.; Schaffner, A.; Weder, W.; Schoedon, G. The nitric oxide synthase cofactor tetrahydrobiopterin reduces allograft ischemia-reperfusion injury after lung transplantation. J. Thorac. Cardiovasc. Surg. 118:726-732; 1999.

[108] Date, H.; Triantafillou, A. N.; Trulock, E. P.; Pohl, M. S.; Cooper, J. D.; Patterson, G. A. Inhaled nitric oxide reduces human lung allograft dysfunction. J. Thorac Cardiovasc. Surg. 111:913-919; 1996.
[109] Rakusan, K. Coronary angiogenesis: from morphometry to molecular biology and back. Ann. NY Acad. Sci. 752:257-266; 1995.

[110] Morbidelli, L.; Chang, C. H.; Douglas, J. G.; Granger, H. J.; Ledda, F.; Ziche, M. Nitric oxide mediates mitogenic effect of VEGF on coronary venular endothelium. Am.J. Physiol. 270:H411-H415; 1996.

[111] Hood, J. D.; Meininger, C. J.; Ziche, M.; Granger, H. J. VEGF upregulates ecNOS message, protein, and NO production in human endothelial cells. Am. J. Physiol. 274:H1054-H1058; 1998.

[112] Feng, Y.; Venema, V. J.; Venema, R. C.; Tsai, N.; Caldwell, R. B. VEGF induces nuclear translocation of Flk-1/KDR, endothelial nitric oxide synthase, and caveolin-1 in vascular endothelial cells. Biochem. Biophys. Res. Commun. 256: 192-197; 1999.

[113] Lee, P. C.; Salyapongse, A. N.; Bragdon, G. A.; Shears, L. L.; Watkins, S. C.; Edington, H. D.; Billiar, T. R. Impaired wound healing and angiogenesis in eNOS-deficient mice. Am. J. Physiol. 277:H1600-H1608; 1999.

[114] Frank, S.; Hubner, G.; Breier, G.; Longaker, M. T.; Greenhalgh, D. G.; Werner, S. Regulation of vascular endothelial growth factor expression in cultured keratinocytes: implications for normal and impaired wound healing. J. Biol. Chem. 270:12607-12613; 1995.

[115] Goumas, G.; Tentolouris, C.; Tousoulis, D.; Stefanadis, C.; Toutouzas, P. Therapeutic modification of the L-arginine-eNOS pathway in cardiovascular diseases. Atherosclerosis 154:255-267; 2001.

[116] Bai, Y.; Sun, L.; Yang, T.; Sun, K.; Chen, J.; Hui, R. Increase in fasting vascular endothelial function after short-term oral L-arginine is effective when baseline flow-mediated dilation is low: a meta-analysis of randomized controlled trials. Am. J. Clin. Nutr. 89:77-84; 2009.

[117] Lass, A.; Suessenbacher, A.; Wolkart, G.; Mayer, B.; Brunner, F. Functional and analytical evidence for scavenging of oxygen radicals by L-arginine. Mol. Pharmacol. 61:1081-1088; 2002.

[118] Adams, M. R.; Jessup, W.; Hailstones, D.; Celermajer, D. S. L-Arginine reduces human monocyte adhesion to vascular endothelium and endothelial expression of cell adhesion molecules. Circulation 95:662-668; 1997.

[119] Watanabe, G.; Tomiyama, H.; Doba, N. Effects of oral administration of L-arginine on renal function in patients with heart failure. J. Hypertens. 18:229-234; 2000.

[120] Bocchi, E. A.; Vilella de Moraes, A. V.; Esteves-Filho, A.; Bacal, F.; Auler, J. O.; Carmona, M. J.; Bellotti, G.; Ramires, A. F. L-Arginine reduces heart rate and improves hemodynamics in severe congestive heart failure. Clin. Cardiol. 23:205-210; 2000.

[121] Creager, M. A.; Gallagher, S. J.; Girerd, X. J.; Coleman, S. M.; Dzau, V. J.; Cooke, J. P. L-Arginine improves endothelium-dependent vasodilation in hypercholesterolemic humans. J. Clin. Invest. 90:1248-1253; 1992.

[122] Stroes, E. S.; Koomans, H. A.; de Bruin, T. W.; Rabelink, T. J. Vascular function in the forearm of hypercholesterolaemic patients off and on lipid-lowering medication. Lancet 346:467-471; 1995.

[123] Mehta, S.; Stewart, D. J.; Langleben, D.; Levy, R. D. Short-term pulmonary vasodilation with L-arginine in pulmonary hypertension. Circulation 92: 1539-1545; 1995.

[124] Schulman, S. P.; Becker, L. C.; Kass, D. A.; Champion, H. C.; Terrin, M. L.; Forman, S.; Ernst, K. V.; Kelemen, M. D.; Townsend, S. N.; Capriotti, A.; Hare, J. M.; Gerstenblith, G. L-Arginine therapy in acute myocardial infarction: the Vascular Interaction with Age in Myocardial Infarction (VINTAGE MI) randomized clinical trial. JAMA 295:58-64; 2006.

[125] Bode-Boger, S. M.; Scalera, F.; Ignarro, L. J. The L-arginine paradox: importance of the L-arginine/asymmetrical dimethylarginine ratio. Pharmacol. Ther. 114: 295-306; 2007.

[126] Heitzer, T.; Krohn, K.; Albers, S.; Meinertz, T. Tetrahydrobiopterin improves endothelium-dependent vasodilation by increasing nitric oxide activity in patients with type II diabetes mellitus. Diabetologia 43:1435-1438; 2000.

[127] Ramzy, D.; Rao, V.; Tumiati, L. C.; Xu, N.; Miriuka, S.; Delgado, D.; Ross, H. J. Tetrahydrobiopterin prevents cyclosporine-induced vasomotor dysfunction. Transplantation 79:876-881; 2005.

[128] Grabowski, P. S.; Wright, P. K.; Van 't Hof, R. J.; Helfrich, M. H.; Ohshima, H. Ralston, S. H. Immunolocalization of inducible nitric oxide synthase in synovium and cartilage in rheumatoid arthritis and osteoarthritis. Br. J. Rheumatol. 36: 651-655; 1997.

[129] Porkert, M.; Sher, S.; Reddy, U.; Cheema, F.; Niessner, C.; Kolm, P.; Jones, D. P.; Hooper, C.; Taylor, W. R.; Harrison, D.; Quyyumi, A. A. Tetrahydrobiopterin: a novel antihypertensive therapy. J. Hum. Hypertens. 22:401-407; 2008.

[130] Katusic, Z. S.; d'Uscio, L. V.; Nath, K. A. Vascular protection by tetrahydrobiopterin: progress and therapeutic prospects. Trends Pharmacol. Sci. 30:48-54; 2009.

[131] Moens, A. L.; Vrints, C. J.; Claeys, M. J.; Timmermans, J. P.; Champion, H. C.; Kass, D. A. Mechanisms and potential therapeutic targets for folic acid in cardiovascular disease. Am. J. Physiol. Heart Circ. Physiol. 294:H1971-H1977; 2008.

[132] Moens, A. L.; Claeys, M. J.; Wuyts, F. L.; Goovaerts, I.; Van, H. E.; Wendelen, L. C.; Van, H. V.; Vrints, C. J. Effect of folic acid on endothelial function following acute myocardial infarction. Am. J. Cardiol. 99:476-481; 2007.

[133] Setoguchi, S.; Mohri, M.; Shimokawa, H.; Takeshita, A. Tetrahydrobiopterin improves endothelial dysfunction in coronary microcirculation in patients without epicardial coronary artery disease. J. Am. Coll. Cardiol. 38:493-498; 2001.

[134] Verhaar, M. C.; Wever, R. M.; Kastelein, J. J.; van, D. T.; Koomans, H. A.; Rabelink, T. J. 5-Methyltetrahydrofolate, the active form of folic acid, restores endothelial function in familial hypercholesterolemia. Circulation 97:237-241; 1998.

[135] Shirodaria, C.; Antoniades, C.; Lee, J.; Jackson, C. E.; Robson, M. D.; Francis, J. M.; Moat, S. J.; Ratnatunga, C.; Pillai, R.; Refsum, H.; Neubauer, S.; Channon, K. M. Global improvement of vascular function and redox state with low-dose folic acid: implications for folate therapy in patients with coronary artery disease. Circulation 115:2262-2270; 2007. 
[136] Laufs, U.; Wassmann, S.; Hilgers, S.; Ribaudo, N.; Bohm, M.; Nickenig, G. Rapid effects on vascular function after initiation and withdrawal of atorvastatin in healthy, normocholesterolemic men. Am. J. Cardiol. 88:1306-1307; 2001.

[137] Merla, R.; Ye, Y.; Lin, Y.; Manickavasagam, S.; Huang, M. H.; Perez-Polo, R. J.; Uretsky, B. F.; Birnbaum, Y. The central role of adenosine in statin-induced ERK1/2, Akt, and eNOS phosphorylation. Am. J. Physiol. Heart Circ. Physiol. 293:H1918-H1928; 2007.

[138] Watanabe, T.; Barker, T. A.; Berk, B. C. Angiotensin II and the endothelium: diverse signals and effects. Hypertension 45:163-169; 2005.

[139] Hisamoto, K.; Ohmichi, M.; Kurachi, H.; Hayakawa, J.; Kanda, Y.; Nishio, Y.; Adachi, K.; Tasaka, K.; Miyoshi, E.; Fujiwara, N.; Taniguchi, N.; Murata, Y. Estrogen induces the Akt-dependent activation of endothelial nitric-oxide synthase in vascular endothelial cells. J. Biol. Chem. 276:3459-3467; 2001.

[140] Kan, W. H.; Hsu, J. T.; Ba, Z. F.; Schwacha, M. G.; Chen, J.; Choudhry, M. A.; Bland, K. I.; Chaudry, I. H. p38 MAPK-dependent eNOS upregulation is critical for 17beta-estradiol-mediated cardioprotection following trauma-hemorrhage. Am. J. Physiol. Heart Circ. Physiol. 294:H2627-H2636; 2008.

[141] Rich, S. The current treatment of pulmonary arterial hypertension: time to redefine success. Chest 130:1198-1202; 2006.
[142] Steiner, M. K.; Preston, I. R.; Klinger, J. R.; Hill, N. S. Pulmonary hypertension: inhaled nitric oxide, sildenafil and natriuretic peptides. Curr. Opin. Pharmacol. 5: 245-250; 2005

[143] Zhao, L.; Mason, N. A.; Morrell, N. W.; Kojonazarov, B.; Sadykov, A.; Maripov, A.; Mirrakhimov, M. M.; Aldashev, A.; Wilkins, M. R. Sildenafil inhibits hypoxiainduced pulmonary hypertension. Circulation 104:424-428; 2001.

[144] Heller, R.; Unbehaun, A.; Schellenberg, B.; Mayer, B.; Werner-Felmayer, G.; Werner, E. R. L-Ascorbic acid potentiates endothelial nitric oxide synthesis via a chemical stabilization of tetrahydrobiopterin. J. Biol. Chem. 276:40-47; 2001.

[145] Fraccarollo, D.; Widder, J. D.; Galuppo, P.; Thum, T.; Tsikas, D.; Hoffmann, M.; Ruetten, H.; Ertl, G.; Bauersachs, J. Improvement in left ventricular remodeling by the endothelial nitric oxide synthase enhancer AVE9488 after experimental myocardial infarction. Circulation 118:818-827; 2008.

[146] Frantz, S. Adamek, A.; Fraccarollo, D; Tillmanns, J.; Widder, J. D. Dienesch, C. Schafer, A.; Podolskaya, A.; Held, M.; Ruetten, H.; Ertl, G.; Bauersachs, J. The eNOS enhancer AVE 9488: a novel cardioprotectant against ischemia reperfusion injury. Basic Res. Cardiol. 104:773-779; 2009. 